\title{
Kingdom of the Netherlands-Netherlands Antilles: Assessment of the Supervision and Regulation of the Financial Sector Volume I-Review of Financial Sector Regulation and Supervision
}

This review of financial sector regulation and supervision in the Kingdom of the NetherlandsNetherlands Antilles in the context of the offshore financial center assessment program contains technical advice and recommendations given by the staff team of the International Monetary Fund in response to the authorities of the Kingdom of the Netherlands-Netherlands Antilles' request for technical assistance. It is based on the information available at the time it was completed in February 2004. The staff's detailed assessment of the observance of standards and codes can be found in Volume II. The views expressed in these documents are those of the staff team and do not necessarily reflect the views of the government of the Kingdom of the Netherlands-Netherlands Antilles or the Executive Board of the IMF.

The policy of publication of staff reports and other documents by the IMF allows for the deletion of market-sensitive information.

To assist the IMF in evaluating the publication policy, reader comments are invited and may be sent by e-mail to publicationpolicy@imf.org.

Copies of this report are available to the public from

International Monetary Fund • Publication Services

700 19th Street, N.W. • Washington, D.C. 20431

Telephone: (202) 6237430 • Telefax: (202) 6237201

E-mail: publications@imf.org • Internet: http://www.imf.org

Price: $\$ 15.00$ a copy

\section{International Monetary Fund Washington, D.C.}



ASSESSMENT OF THE SUPERVISION AND REgULATION OF THE FinANCIAL SECTOR

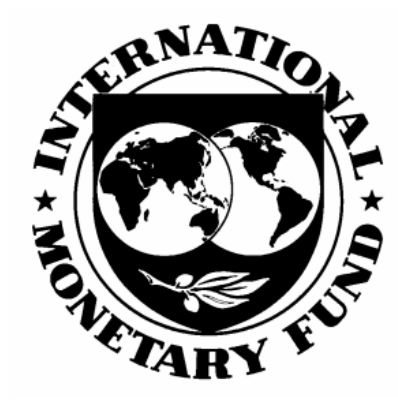

Volume I: Review of Financial Sector Regulation and Supervision

\section{Kingdom of the Netherlands - Netherlands Antilles}

FEBRUARY 2004 
The contents of this report constitute technical advice and recommendations given by the staff of the International Monetary Fund to the authorities of a member country in response to their request for technical assistance. With the written authorization of the recipient country's authorities, this report (in whole or in part) or summaries thereof may be disclosed to IMF Executive Directors and their staff, and to technical assistance providers and donors outside the IMF. Disclosure of this report (in whole or in part) or summaries thereof to parties outside the IMF other than technical assistance providers and donors shall require the written authorization of the recipient country's authorities and the IMF's Monetary and Financial Systems Department. 
Preface.

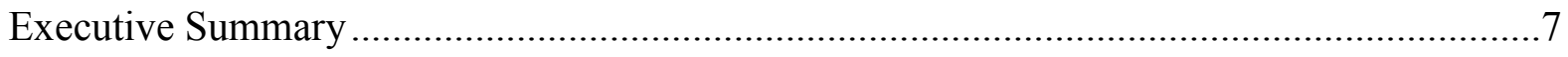

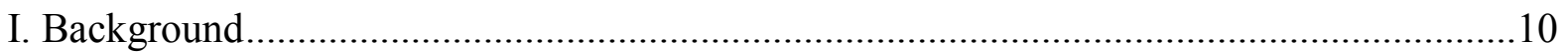

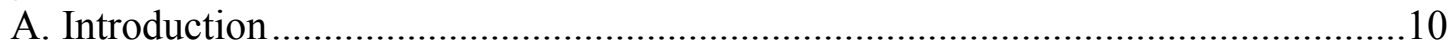

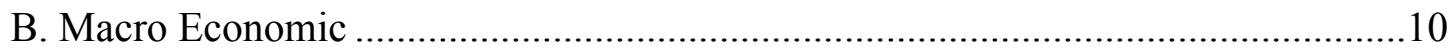

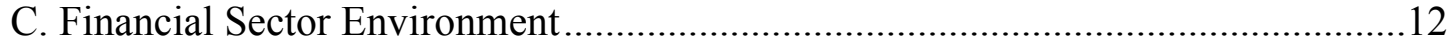

II. Other International Assessments of the Netherlands Antilles........................................13

III. The Netherlands Antilles as an Offshore Financial Center ...........................................14

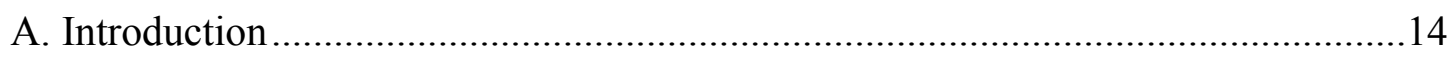

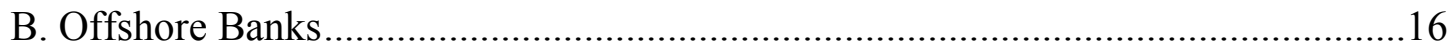

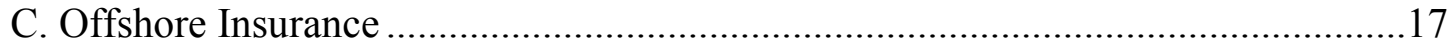

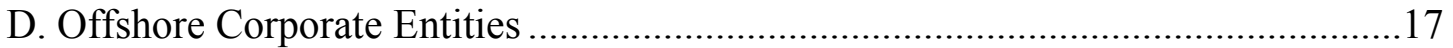

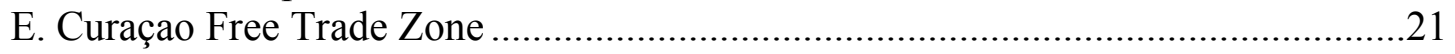

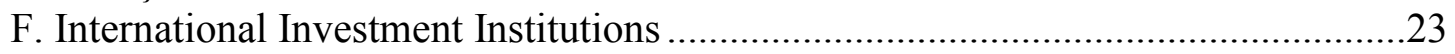

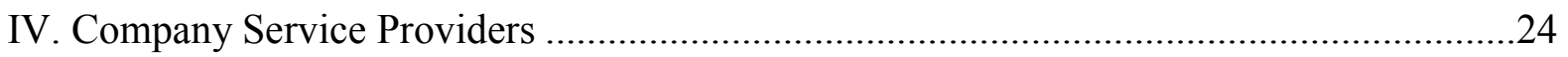

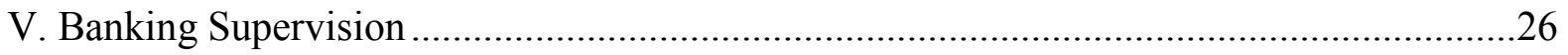

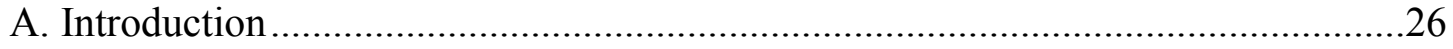

B. Basel Core Principles Assessment-Main Findings ......................................28

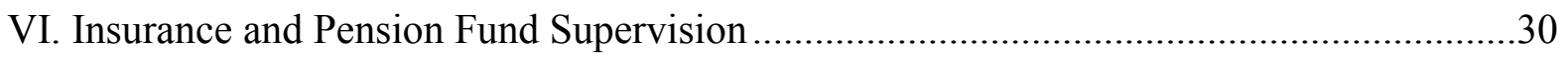

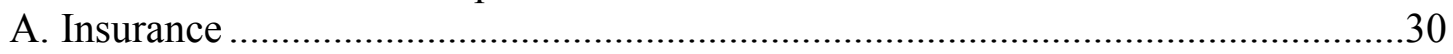

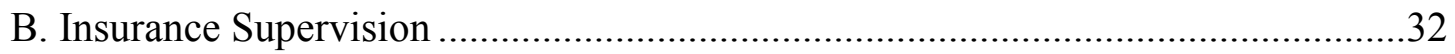

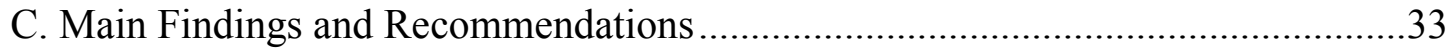

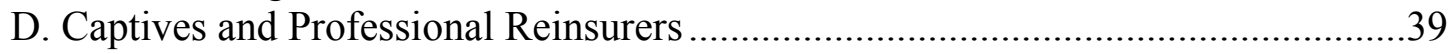

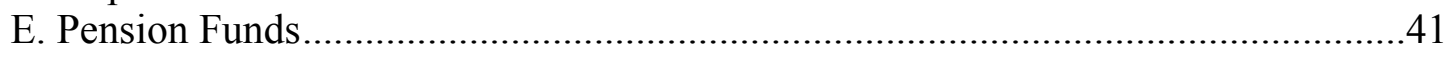

VII. Anti-Money Laundering and Combating Financing of Terrorism-Summary

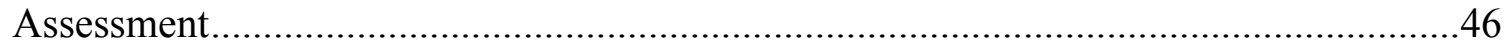

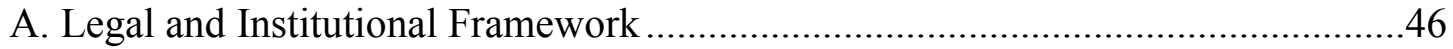

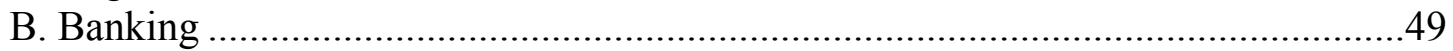

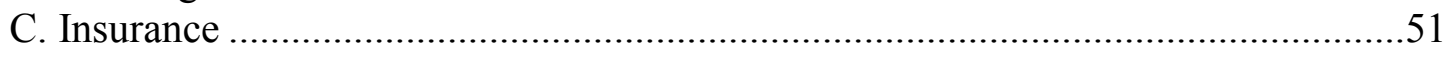

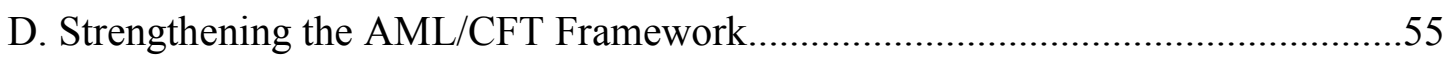




\section{Tables}

1. Aggregate Balance Sheet of Commercial Banks Operating in the International Banking Sector at Year-End

2. International Debt Securities by Country of Residence..........................................19

3. Curaçao Free Trade Zone, Customs Value ..............................................................21

4. Aggregate Balance Sheet of Commercial Banks Operating in the Domestic

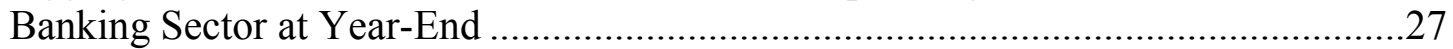

5. Summary Compliance of the Basel Core Principles...............................................28

6. Insurance Sector-Total Admissible Assets........................................................3

7. Insurance Companies in the Netherlands Antilles at End-2001 ................................31

8. Consolidated Balance Sheet of Life Insurance Companies ......................................31

9. Consolidated Balance Sheet of the Nonlife Insurance Industry ................................32

10. Compliance with the FATF Recommendations and Eight Special

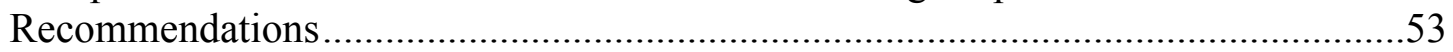

Figures

1. Composition of the Institutional Investor's Sector ................................................18

Attachment

I. Comments on Company Service Provider Legislation. 


\section{GLOSSARY}

$\begin{array}{ll}\text { AML } & \begin{array}{l}\text { Anti-money laundering } \\ \text { Algemeen Pensioen Fonds Nederlandse Antillen } \\ \text { (Civil Service Pension Fund) }\end{array} \\ \text { ARAS } & \text { Annual Report Automated Statements } \\ \text { BCP } & \text { Basel Core Principles } \\ \text { BIS } & \text { Bank for International Settlements } \\ \text { BNA } & \text { Bank of the Netherlands Antilles } \\ \text { BRK } & \text { Belasting Regeling Koninkrijk } \\ \text { CFATF } & \text { Caribbean Financial Action Task Force } \\ \text { CFT } & \text { Combating financing of terrorism } \\ \text { CP } & \text { Core Principle } \\ \text { CSP } & \text { Company service providers } \\ \text { FATF } & \text { Financial Action Task Force } \\ \text { FIU } & \text { Financial Intelligence Unit } \\ \text { FSF } & \text { Financial Stability Forum } \\ \text { GAAP } & \text { General Accepted Accounting Principles } \\ \text { IAIS } & \text { International Association of Insurance Supervisors } \\ \text { INCSR } & \text { U.S. Internal Narcotics Control Strategy Report } \\ \text { IRS } & \text { U.S. Internal Revenue Service } \\ \text { KYC } & \text { Know your customer } \\ \text { MoUs } & \text { Memoranda of understanding } \\ \text { MT } & \text { Money transmitter } \\ \text { NA f. } & \text { Netherlands Antillean Guilders, or Florin } \\ \text { NFR } & \text { New fiscal regime } \\ \text { OECD } & \text { Organization for Economic Cooperation and Development } \\ \text { QI } & \text { Qualified Intermediary } \\ \text { P\&C } & \text { Property and casualty } \\ \text { SOCPF } & \text { State Ordinance on Corporate Funds } \\ \text { UTRC } & \text { Unusual Transactions Reporting Center } \\ & \\ \text { ATH } & \end{array}$




\section{Preface}

At the request of the authorities, a Module II offshore financial center assessment of the Netherlands Antilles was carried out during a two-part MFD/LEG mission, January 14-18 and April 15-24, 2002. ${ }^{1}$ An update was performed by written procedure and in a series of telephone conferences with the authorities in May and June 2003. In its assessment, the mission reviewed offshore as well as onshore regulation and supervision. A review of both onshore and offshore activities was considered appropriate as supervision of both sectors is identical, with the exception of supervision over captive insurance companies and professional reinsurers. Furthermore, supervision is exercised by the same agency and review of both onshore and offshore supervision is necessary for an adequate assessment of the authorities' treatment of the risks associated with offshore financial business. Onshore banking supervision is also relevant to the effectiveness of anti-money laundering/combating financing of terrorism (AML/CFT) policies and practices.

The mission met with the Dr. E.D. Tromp, President of the Bank of the Netherlands Antilles; Mr. R.S.J. Martha, Minister of Justice; Mr. S. Betrian, Chairman of the Supervisory Board for Company Service Providers; Ms. H. Chirino Roosberg, Head of the Reporting Center for Unusual Transactions; ${ }^{2}$ Ms. Deborah Bolton, Consul General of the United States; Mr. S. Salesia, Deputy Director of the Bank of the Netherlands Antilles for Banking Supervision; Mr. U. Dalnoot, Head of Banking Supervision Examinations; Mr. R. Rooi, Head Banking Supervision General; Mr. H.L. Willems, Head Policy Department; Mrs. N. Davelaar, Deputy Director Institutional Investors and Investment Institutions; Ms. R. Garcia, Deputy Director of the Bank of the Netherlands Antilles for International Relations; Ms. S. Herrera, Head of International Relations; Mr. E. Smeulders, Managing Director of the Curaçao Free Zone; representatives of commercial banks, insurance companies, members of the legal and notarial professions; and other private and public sector representatives in the financial, anti-money laundering, and law enforcement fields.

The authorities of the Netherlands Antilles agreed to the use of the full Basel Core Principles (BCP) Methodology for the assessment of banking supervision and regulation, including the essential and additional criteria, as well as the MFD Anti-Money Laundering and counterterrorist-finance methodology developed by MFD, in its February 2002 version.

The mission wishes to express its sincere gratitude for the hospitality, flexibility, and excellent cooperation of the authorities, which contributed greatly to the success of the mission.

${ }^{1}$ The IMF's Monetary and Exchange Affairs Department (MAE) was renamed Monetary and Financial Systems Department (MFD) as of May 1, 2003. The new name has been used throughout this document.

${ }^{2}$ The Financial Intelligence Unit (FIU). 


\section{EXECUTIVE SUMMARY}

The Netherlands Antilles has taken the initiative to undergo a full Module I and II Offshore Financial Center assessment, comprising a Fund-assisted self assessment of compliance with international standards on banking and insurance supervision, as well as on AML/CFT (Module I), and an external Fund assessment (Module II).

This initiative underscores the authorities' determination, in the face of budget and staff constraints, to continue their ongoing program to upgrade financial sector supervision and AML/CFT efforts for the offshore as well as the onshore sectors. Together with other parts of the Kingdom of the Netherlands, a concerted effort is underway to introduce more explicit and focused anti-terrorism legislation and regulation.

Furthermore, the Netherlands Antilles is resolved to remove the perception created by placement of the jurisdiction in the weakest category of the list of offshore financial centers, published by the Financial Stability Forum (FSF).

Overall, the legal and institutional framework for financial sector supervision meets high standards. It is comprehensive, effective, and to great extent in line with international standards. Bank of the Netherlands Antilles (BNA) staff is highly capable, well-trained and dedicated, and is able to attract appropriate personnel and material resources to perform its functions.

Banking supervision is compliant or largely compliant with the great majority of the Basel Core Principles. The banking system is stable and adequately capitalized. The legal and regulatory structure of banking supervision is very good. However, the nexus of adequate loan classification and provisioning, and the supporting on-site and off-site supervision functions, requires a more proactive approach, in particular, in the current economic situation. Verification of the quality of assets and AML/CFT compliance by on-site inspections of once every 1-2 years, based on the assumption that the banks, as well as their external auditors, will address asset quality in a sufficiently rigorous way, may not be sufficient. In March 2003, the BNA issued a new policy rule on integrity testing of managers of banks.

Several signals support this conclusion. Banks have been required to operate in a deteriorating economic environment. Nonperforming loans are rising, returns on assets are falling, and there are signs that rollovers and capitalization of interest could be increasing. Furthermore, banks' reporting on their problem loans, according to the normal schedule used to support Regulation No. V, does not address the economic and repayment prospects of the borrower.

The mission would, therefore, recommend engaging in a specific exercise within the banking supervision department to analyze the condition and the prospects of the banks, specifically, with a view to assessing asset quality based on review of their files and focused on the economic prospects of the borrowers. Follow-up with the banks should include risk-oriented 
discussions of the portfolios that give rise to concern. Subsequently, decisions need to be taken on appropriate provisioning levels.

Insurance supervision is also observant or broadly observant with the great majority of the International Association of Insurance Supervisors (IAIS) Core Principles, and supervisory staff is of high quality. Although more detailed recommendations are included in the Action Plan, some issues can be highlighted here. The mission recommends that the current, lighter, regulatory regime for captive and professional reinsurance supervision be replaced for more rigorous approach applied to onshore insurance companies, including licensing requirements. More extensive contacts and structures for cooperation with insurance supervisors abroad are also needed, through exchange of information and conclusion of more memoranda of understanding (MoUs). The BNA may wish to consider joining the newly created International Association of Pension Supervisors. In general, the mission strongly supports the review of pension legislation, with a view to strengthening the position of pensioners, transparency of the financial condition of the funds, and removing the excessively lenient exemptions clause in the current law.

AML/CFT framework. In general, the AML/CFT legal and institutional framework is comprehensive and well designed. However, there are some areas to be strengthened as follows: nonlife insurance companies, as well as lawyers, notaries, accountants, consultants, real estate agents, and dealers in high-end goods, such as antiques, jewelry, and auctioneers, are not currently covered by the AML/FT framework.

Per June 2003, new AML/CFT guidelines have been issued by the BNA for financial institutions and intermediaries. An explicit statutory requirement that financial institutions screen applicants for employment to prevent the use of their institutions by money launderers or terrorists is needed. Also, in March 2003, a new Integrity Test was introduced by the BNA for managers of supervised financial institutions. On-site AML/CFT inspections by the BNA and other agencies, including the Company Service Providers (CSP) Supervisory Board and the local Gaming Control Board, should occur on a more frequent basis. Finally, the legal authority to impose, with a court order if necessary, civil money penalties (administrative fines) should be granted to the BNA, the Gaming Control Board, the Unusual Transactions Reporting Center (UTRC), the FIU, and the CSP Supervisory Board, for violations of law, including AML/CFT laws. In the fall of 2002, several measures were taken by the authorities to strengthen the AML/CFT framework, for instance, by creating an obligation to report activities related to the financing of terrorism to the UTRC. An enhanced program of AML on-site inspections of insurance companies was started in March 2003. Draft legislation to include nonlife insurance companies, underwriters, brokers and agents under AML/CFT legislation was submitted to parliament.

Company service providers. While it is helpful that CSPs have been brought under the supervision of a regulatory entity, consideration could be given to allocate supervision to the BNA. The BNA already regulates banks, insurance companies, pension funds, investment institutions, and fund administrators. In addition, this approach is consistent with an 
increasing trend to consolidate regulation and supervision of financial activities internationally, including in the Netherlands.

The mission has agreed with the authorities on the elements of a comprehensive prioritized action plan, to address remaining issues. ${ }^{3}$

${ }^{3}$ See Volume II of this report. 


\section{BACKGROUND}

\section{A. Introduction}

1. In July 2000, the Executive Board of the IMF approved a program of assessments of the extent to which offshore financial centers observed good standards of international practice with regard to the supervision and regulation of offshore financial services. The program of assessments is based on the paper presented to the Executive Board "Offshore Financial Centers - The Role of the IMF."4 This paper proposed a two-phase assessment process: a Module I assessment, consisting of a self-assessment performed by the jurisdiction itself, assisted by experts or Fund staff, and a Module II assessment, consisting of an external assessment carried out by the Fund. The authorities of the Netherlands Antilles have carried out a Fund-assisted self assessment, for which missions consisting of staff of the Fund's Monetary and Financial Systems Department and a consultant of the Legal Department visited the Netherlands Antilles in December 2000 and April 2001.

\section{B. Macro Economic}

2. The Netherlands Antilles consists of a federation of five islands, ${ }^{5}$ located in the southeastern Caribbean, with a population of approximately 175,000. The Netherlands Antilles is an autonomous but integral part of the Kingdom of the Netherlands. It is a small open economy, with a GDP for the year 2002 of approximately US\$2.7 billion, providing a per capita income of US\$15,600. The domestic currency, the Netherlands Antillean guilder (NA f.) has been pegged to the U.S. dollar at a rate of NA f. 1.79 per $\$ 1$ since December 23, 1971.

3. The economy relies primarily on three sectors: offshore financial services, oil refining, and transportation and tourism, and is thus only moderately diversified. It has suffered severely over the past decade from declines in these inflows and a series of hurricanes that have hit St. Maarten in the second half of the nineties. The offshore financial services sector suffered a severe decline as a result of changes in tax legislation in other jurisdictions. Tax revenue received from the sector declined from about 20 percent of GDP in the mid-1980s, to less than 2 percent of GDP in 2002. After some years of depressed tourism revenues, resulting from the September 11 impact, the economic slowdown in the United States and the effects of events in Venezuela in 2001 and 2002 have shown signs of recovery, with an estimated 2 percent increase in cruise tourism over 2002, and continued

${ }^{4} \mathrm{SM} / 00 / 136(6 / 23 / 2000)$.

${ }^{5}$ Bonaire and Curaçao (the Leeward Islands) and Saba, St. Eustatius and the southern part of St. Maarten (the northern part is a French territory): the Windward Islands; each island has a separate government. The central government of the Netherlands Antilles is established in Curaçao. 
growth expected in 2003. The economy also suffers from continued emigration of skilled labor to the Netherlands, although the weaker job market in the Netherlands has slowed this trend.

4. In 1997, the Netherlands Antilles entered a prolonged recession. Real GDP declined by some 12 percent since 1996, primarily as a result of external shocks and inadequate policies. Economic contraction was accompanied by a sharp rise in inflation, from 0.8 percent in 1999 to 5.0 percent in 2000, mainly as a result of rising world oil prices and the impact of indirect taxes. However, inflation declined to 0.4 percent in 2002. Unemployment decreased from 14.1 percent in 1999 to 12.9 percent in 2000 , mainly as a result of migration. In 2001, unemployment rose to 14 percent. Starting in 2001, the economy has shown a modest upturn, however, with an estimated $3 / 4$ percent growth over 2001-02. Further growth of $1 / 2$ percent is projected for 2003. Private investment has increased 20 percent, air travel capacity has increased, and the offshore sector is also showing signs of recovery.

5. Important structural reforms over the past three years may have led to these improvements, including liberalization of air traffic, the abolishment of production monopolies and import quotas, more flexible work arrangements, and the lifting of the individual dismissal permit requirement for most sectors. Measures to promote privatization, e-commerce, and international financial services were also implemented.

6. Public finances have deteriorated sharply. Falling revenue collection and increased interest expenditure have raised the general government deficit by $1 \frac{1 / 4}{4}$ percent of GDP, to a historical high of $5 \frac{1}{2}$ percent of GDP. The central bank is said to have provided net credit to the government to an amount equaling 1.0 percent of GDP in 2001, in part to help eliminate government payment arrears, which were having knock-on effects on the quality of banks' credit portfolios.

7. The external accounts have improved over 2002. The current account deficit stood at an estimated 43/4 percent of GDP, slightly below the average since 1995 , boosted by increased tourism inflows and growth in the Curaçao Free Zone. In addition, the offshore sector is recovering somewhat after the introduction of the new tax framework with the Netherlands. Foreign reserves have increased to the central bank target of three months of imports. Traditional merchandise experts have declined by some 12 percent over the last two years.

8. Although somewhat down from the buoyant levels of 2001, growth of money was still strong at $11 \frac{3}{4}$ percent over 2002 , mainly as a result of continuing foreign exchange inflows. Bank credit to the government increased significantly after the ceiling on this type of credit was lifted, promoted further by the relative attractive yield on government securities compared to foreign alternatives. Up to 2001, insurance companies and pension funds were less willing to refinance government debt and to extend mortgage credit, in view of falling real estate values. With public debt at 75 percent of GDP, decreased confidence in government paper has led to increased bank deposits as a perceived safer investment. 
However, in 2002, investment in government securities was boosted by its attractive yield compared to investments abroad.

9. The banking system shows some improvement in 2002, after conditions had weakened in the years before, reflected by a deterioration in the quality of the loan portfolio, in part due to the slide in real estate values. Nonperforming loans have decreased somewhat, and the level of provisions against nonperforming loans has increased. A more flexible onsite inspection schedule has been introduced. Special administration has been imposed on one undercapitalized bank. Vigilance remains necessary in light of banks' high exposure to the real estate market, continued slow growth, the potential for enhanced competition as structural reforms are implemented, and potential spillover effects from the situation in Venezuela.

\section{Financial Sector Environment}

10. The Netherlands Antilles have a well-developed and well-functioning legal and regulatory framework for financial sector supervision. The BNA is fully responsible for financial sector oversight and combines banking, insurance, pension fund, and mutual fund supervision. Onshore as well as offshore financial institutions are under BNA supervision. The BNA follows strict bank licensing policies and only accepts applications from reputable banks.

11. The laws and regulations are for the most part compliant or broadly compliant with international standards on banking supervision, insurance supervision, AML/CFT, and investment institution supervision. The authorities are proactive in developing new techniques and policies to keep up with international developments. It is undertaking strong efforts, together with other parts of the Kingdom of the Netherlands, to strengthen standards against terrorist finance.

12. The financial sector benefits greatly from a strong general legal and judicial framework, the presence of well-trained legal, taxation, accounting, auditing, and company management professionals. Most professional categories, such as civil law notaries, lawyers, and accountants/auditors work under well-established codes of conduct.

13. The civil code and companies laws are based on the European continental systems. Loan contracts, enforcement, and security mechanisms function well; mortgages can be foreclosed without court intervention, and effective bankruptcy rules are in place and can be implemented. The Antilles is used as a basis for the issue of large volumes of international debt securities.

14. Traditionally, the business environment in the Netherlands Antilles has operated under a regime of relatively little disclosure. Many companies were not obliged to disclose financial information nor the identity of the shareholders or beneficial owners. The offshore companies were almost completely "black boxes." 
15. Under the pressure of events during recent years, increased international efforts to combat drug trafficking and money laundering, anti-terrorism efforts, greater awareness of the importance of better quality financial sector supervision, and less tolerance for excessively favorable tax regimes in many offshore jurisdictions have changed the traditional outlook. The perception that the business community, onshore as well as offshore, should continue to be protected from public scrutiny as much as possible has changed. The authorities, but also the private sector, are aware that more disclosure is needed to comply with a growing body of international standards. Public and private sectors agree that there is no option but to "regulate up."

16. In August 2001 company service providers, which have since decades been the managers of the offshore corporate vehicles, were placed under supervision of the Supervisory Board for Fiduciary Business, under the responsibility of the minister of justice. This will oblige the company service providers to apply Know Your Customer (KYC) rules and report unusual transactions to the authorities. Also, more customer due diligence will result from the implementation of the commitment to the Organization for Economic Cooperation and Development (OECD) to eliminate harmful tax practices.

\section{Other International Assessments of the Netherlands Antilles}

17. The Netherlands Antilles has been subject to other assessments of their AML policies and practices and financial sector supervision.

\section{Financial Stability Forum}

18. On the grounds of a perception-based survey of the FSF, published in April 2000, the Netherlands Antilles were classified as a jurisdiction "generally perceived as having legal infrastructures and supervisory practices and/or a level of resources devoted to supervision and cooperation that are largely of a lower quality."

\section{Financial Action Task Force (FATF)}

19. In a second FATF mutual evaluation performed in 1999, the Netherlands Antilles were evaluated favorably with regard to their AML framework. The FATF concluded its report by stating: "Overall, considerable efforts have been made in the last four years, and though much of the system is very recent, the penal legal system is nearly in place, an operational structure is established, and the basic preventive measures are now in place in the banking sector. Though further refinements are required and additional measures are necessary in relation to NBFI and nonfinancial businesses, particularly the offshore sector, further experience is needed before a complete assessment can be made of the effectiveness of the system as a whole." 


\section{U.S. International Narcotics Control Strategy Report (INCSR)}

20. Although the island of St. Maarten still poses significant problems in the area of drugs trafficking and the implementation of AML measures, and understaffing of the police and the UTRC (the Antillean financial intelligence unit) needs to be addressed, the 2002 INCSR is positive about the cooperation of the Netherlands Antilles authorities with U.S. investigation, law enforcement, and judicial authorities. Cooperation in prosecuting international and more complex drug trafficking cases is becoming more effective. The Netherlands Antilles confirmed their commitment to the fight against drug trafficking through continued support for the U.S. Forward Operating Location at the international airport of Curaçao. In October 2001, a new 10-year lease contract was ratified providing a base for U.S. military aircraft to conduct detection and monitoring flights from commercial space at the airport, free of charge. During 2001, the Netherlands Antilles have continued their program of implementation of improved AML legislation and regulation. The authorities have shown a commitment to the fight against money laundering by establishing solid AML/CFT rules and policies.

\section{U.S. Internal Revenue Service (IRS)}

21. The IRS has granted the Netherlands Antilles, as well as some individual financial institutions, "Qualified Intermediary" (QI) status. A jurisdiction requires QI status before U.S.-taxed citizens can be eligible for relief of withholding tax on revenues paid from within that jurisdiction to these U.S. citizens. In order to obtain QI status, the IRS must recognize the $\mathrm{KYC}$ rules of that jurisdiction as sufficiently rigorous.

\section{The Netherlands Antilles as an OffShore Financial Center}

\section{A. Introduction}

22. The attractiveness of the Netherlands Antilles as an offshore financial center is based on the following main factors:

- $\quad$ an attractive tax regime and tax treaty system for offshore companies;

- $\quad$ freedom of capital movements;

- $\quad$ limited financial disclosure;

- $\quad$ limited disclosure of ownership/beneficial ownership of companies;

- $\quad$ good legal and judicial system;

- $\quad$ good quality financial and company services;

- $\quad$ political stability; and

- convenient location and communications. 
23. In mid-2001, the Netherlands Antilles and the Netherlands concluded a new tax agreement, Belasting Regeling Koninkrijk (BRK) ${ }^{6}$ governing the taxation of dividend flows between the two jurisdictions. Effective January 1, 2002, the Netherlands tax authorities will collect 8.3 percent dividend tax on payments going to the Netherlands Antilles - the current regime requires the Netherlands authorities to collect 5 percent and the Antillean authorities to collect 3.3 percent — and to transfer the proceeds to the Antillean government. This will bring the mutual dividend tax regime between the Netherlands and the Netherlands Antilles in compliance with relevant EU guidelines. Although this result is less than hoped for-some would have preferred a zero rate, which would have been difficult to accept for the OECDthe arrangement restores certainty to the tax arrangements and provides a firm basis for renewed negotiations with other jurisdictions on avoidance of double taxation. In addition, the new fiscal regime (NFR), which parliament approved in December 1999, had been adjusted to be in line with the new BRK. The NFR eliminated, amongst other things, the distinction between onshore and offshore activities (i.e., ring fencing) to end the association with harmful tax practices by the OECD and the European Union.

24. In 2001, tax revenues from the offshore sector amounted to some 2 percent of GDP. ${ }^{7}$ Total contribution to the economy, including employment, is estimated at around 8 percent of GDP. It employs more than 5 percent of the labor force. Per June 2001, 14 percent of the international debt securities issued from offshore financial centers originated from the Netherlands Antilles. ${ }^{8}$ The offshore financial sector consists of banks, life insurance, and nonlife insurance with roughly estimated combined assets of US\$36 billion, of which, 96 percent is held by the banks.

25. The Netherlands Antilles offshore sector mainly provides services in the field of tax planning, based on a network of tax treaties with industrialized countries. In the context of the potential impact on offshore financial services, the mission reviewed the status of the BRK between the Netherlands Antilles and the Netherlands, which is expected to have consequences for the use of the tax treaty network. Also on other grounds, the future of the offshore sector has recently become more uncertain, owing to increased integration of global markets, making the earlier position of the Antilles less unique, as well as increased scrutiny and calls for more disclosure.

\footnotetext{
${ }^{6}$ See Chapter III, prepared by Gerwin Bell in IMF: Kingdom of the NetherlandsNetherlands Antilles, Recent Developments, Selected Issues, and Statistical Appendix, (SM/01/122; 04/23/01).

${ }^{7}$ Source: BNA Quarterly Bulletin, Q IV 2000.

${ }^{8}$ Source: Bank for International Settlements (BIS).
} 


\section{B. Offshore Banks}

26. At end-2001, 45 offshore banks were active in the Netherlands Antilles. End-2000, their balance sheet total was US\$35 billion, as shown in Table 1.The banks are primarily of Venezuelan and Netherlands origin. Supervision of offshore banks is identical to that exercised over onshore banks. Activities of these banks seem to focus on nonbank offshore companies. They are not permitted to have any dealings with residents.

Table 1. Aggregate Balance Sheet of Commercial Banks Operating in the International Banking Sector at Year-End

(In billions of Netherlands Antille Guilders)

\begin{tabular}{|c|c|c|c|c|c|c|}
\hline & \multicolumn{2}{|c|}{2000} & \multicolumn{2}{|c|}{2001} & \multicolumn{2}{|c|}{2002} \\
\hline & NA f. & Percent & NA f. & Percent & NA f. & Percent \\
\hline \multicolumn{7}{|l|}{ Assets } \\
\hline Cash and banks & 11.4 & 18.4 & 15.1 & 22.1 & 14.1 & 18.6 \\
\hline Investments & 4.3 & 6.9 & 4.5 & 6.6 & 4.2 & 5.5 \\
\hline Loans & 33.8 & 54.5 & 38.1 & 56.0 & 42.2 & 55.7 \\
\hline Inv. unconsolidated subs. & 0.2 & 0.3 & 2.1 & 3.1 & 5.3 & 7.0 \\
\hline Fixed assets & 0.1 & 0.1 & 0.1 & 0.1 & 0.1 & 0.1 \\
\hline Other assets & 12.1 & 19.8 & 8.2 & 12.0 & 9.9 & 13.1 \\
\hline Total assets & 61.9 & 100.0 & 68.1 & 100.0 & 75.8 & 100.0 \\
\hline \multicolumn{7}{|l|}{ Liabilities } \\
\hline Demand deposits & 4.8 & 7.7 & 6.4 & 9.4 & 7.6 & 10.0 \\
\hline Savings deposits & 0.2 & 0.3 & 0.2 & 0.3 & 0.4 & 0.5 \\
\hline Time deposits & 15.2 & 24.5 & 13.0 & 19.1 & 12.3 & 16.2 \\
\hline Total deposits & 20.2 & 32.5 & 19.6 & 28.8 & 20.3 & 26.7 \\
\hline Borrowings & 35.0 & 56.5 & 40.7 & 59.8 & 47.8 & 63.1 \\
\hline Other liabilities & 1.0 & 1.7 & 1.1 & 1.6 & 1.1 & 1.5 \\
\hline Total liabilities & 56.2 & 90.7 & 61.4 & 90.2 & 69.2 & 91.3 \\
\hline Minority interest & 0.1 & 0.2 & 0.9 & 1.3 & 2.0 & 2.6 \\
\hline Subordinated debentures & 0.0 & 0.0 & 0.0 & 0.0 & 0.0 & 0.0 \\
\hline General provisions & 0.3 & 0.5 & 0.2 & 0.3 & 0.2 & 0.3 \\
\hline Capital and reserves & 5.3 & 8.6 & 5.6 & 8.2 & 4.4 & 5.8 \\
\hline Total capital & 5.7 & 9.3 & 6.7 & 9.8 & 6.6 & 8.7 \\
\hline Total liabilities and capital & 61.9 & 100.0 & 68.1 & 100.0 & 75.8 & 100.0 \\
\hline
\end{tabular}

Source: Bank of the Netherlands Antilles. 
27. The difference in the nature of onshore versus offshore banking lies primarily in the clientele of the institutions, and the absence of cash-based transactions in the offshore sector. Onshore banks' activities consist of slightly over 50 percent of lending, funded by customer deposits (87 percent of the balance sheet total per June 2003). Also, cash transactions, securities transactions, custodial services, and foreign exchange services are performed. Offshore banking services nonresident customers and focuses on international banking operations, consisting of services to companies ("trust" business), mutual funds, and (re)insurance companies. Nonresident legal entities, with ultimate ownership outside the Antilles, are free to perform international capital transactions with nonresidents. Since the introduction of the New Fiscal Framework with the Netherlands, differentiation in tax treatment between offshore and onshore entities no longer occurs.

28. Offshore banks have diverse types of business. Most are subsidiaries or branches of large financial institutions in Europe, the United States, or South America. Some banks are primarily involved in private banking and asset management, whereas others are merely loan booking offices. Some banks act as a treasurer for a larger conglomerate or have a role as a regional credit office. Funding can reflect this diversity; from within the group, or from other financial institutions. All clients need to be nonresidents.

29. The risks in the offshore business are comparable to those of the onshore business and are related to the types of business. In general, market risk, credit risk, interest rate risk, and operational and political risks are comparable to in the onshore business. Reputational risk is higher for private banking institutions, as clients reside abroad, which can require additional investigation as to the identity of the customer and the source of the funds.

\section{Offshore Insurance}

30. The offshore insurance sector consisted of 21 companies at the end of 2001, of which 5 were reinsurance companies and 16 captive insurance companies (one life and 15 nonlife) (Figure 1). Most have European parents; more than 50 percent have parent companies in the Netherlands. Net premium income of the offshore life insurance companies in 2000 amounted to US\$5.0 million while for nonlife the net premium income is US\$212.2 million.

31. The types of risks being insured primarily by the offshore insurance sector are liability, motor, property, and some marine insurance. The greater number of nonlife insurance companies may relate to the larger number of nonlife types of risk that are insured, leading to a larger number of specialized institutions. Many of the large nonlife risks are ceded to companies abroad, as the local market is too small.

\section{Offshore Corporate Entities}

32. Currently, some 20,000 active offshore corporate entities are registered as a corporation, Netherlands Antilles private foundations, or partnerships, with owners in the United States, the Netherlands, East Asia, Spain, Italy, and Latin America. In 2001, 534 new offshore companies were registered, 205 removed from the register, 170 liquidated, 
Figure 1. Composition of the Institutional Investor's Sector

(Number of Companies)

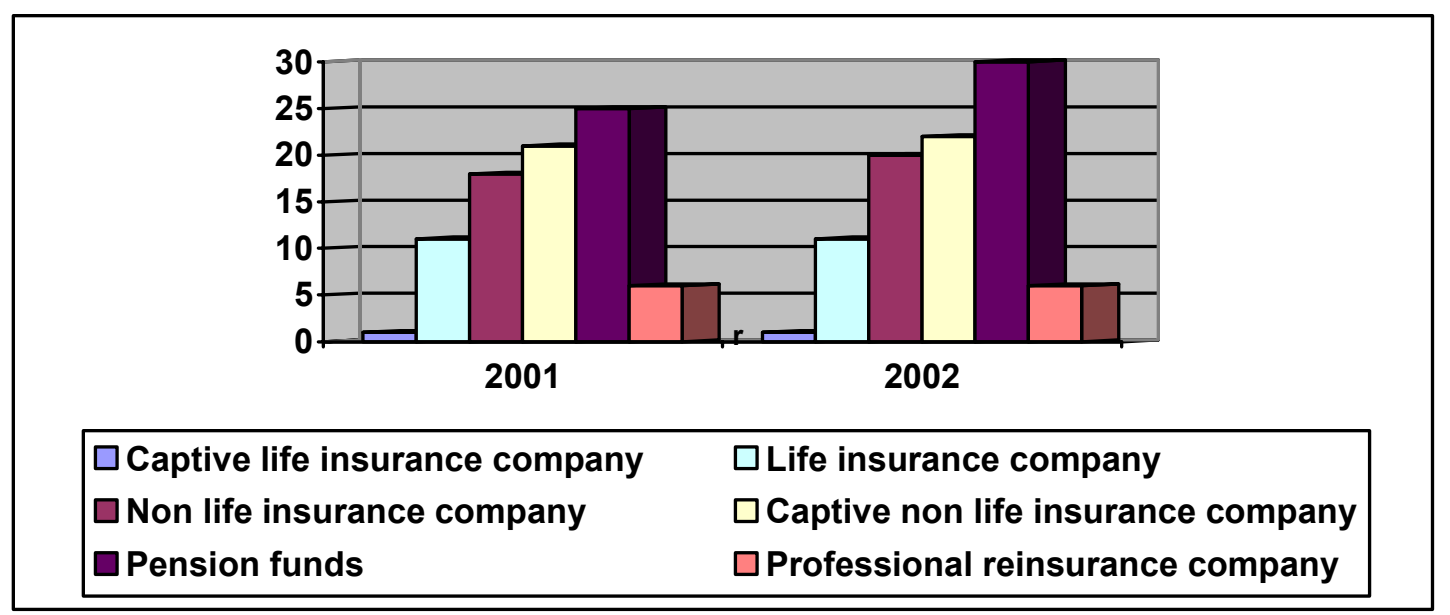

Source: Bank of the Netherlands Antilles.

and 29 reactivated. ${ }^{9}$ The number of offshore companies shows a steady downward trend, with the number of registered companies falling from 20,550 at end-1997 to 19,777 at end2001. The beneficial owners tend to be foreign corporations as well as high net worth individuals. Their activities cover tax planning, captive banking and insurance, special purpose vehicles, and asset management. A number of holding companies are established in the Antilles, of which, the subsidiaries are mostly engaged in investment and intellectual property holdings, as well as shipping, trading, financing, and investment institutions. Companies in the Netherlands Antilles are not subject to mandatory auditing requirements.

33. The offshore corporate entities are in majority managed by some 190 company service providers. Of these, 70 are specialized in financial services, of which again half belong to an international group with the head office in the Netherlands Antilles. There are 45 offshore banks operating in the Netherlands Antilles, with total assets of some US $\$ 35$ billion, or about 1,400 percent of 1997 GDP. The banks mostly have Netherlands or Venezuelan parent companies (for subsidiaries) or head offices (for branches).

34. Approximately 600 of these offshore corporate entities are administrative vehicles for offshore investment institutions, of which between 60 percent and 70 percent are administered by the two largest CSPs. The authorities intend to adopt legislation to place these investment institutions under the supervision of the BNA.

\footnotetext{
${ }^{9}$ Source: Companies Registry at the Chamber of Commerce.
} 
35. Another important function of these companies is to issue debt securities for nonresident borrowers. According to BIS data, and as shown in Table 2, an amount of almost US $\$ 90$ billion, or almost 13 percent of all international debt securities issued from offshore financial centers, originates from the Netherlands Antilles. If outlier Cayman Islands (66 percent of the total) is excluded, the percentage increases to 38 percent.

36. These corporate entities are most frequently used for tax minimization purposes, benefiting from the system of tax treaties to which the Netherlands Antilles have access. Offshore companies managed or controlled from the Netherlands Antilles are considered tax residents in the Antilles. Profit tax rates applicable to these companies range between 2.4 percent for companies channeling revenues from intellectual property to 15 percent for companies channeling dividends, royalties, or interest income. Under the tax treaties, payments by these companies to the beneficial owner, after having been taxed at these low rates in the Netherlands Antilles, are exempt from most or all taxation in the home country of the beneficial owner.

Table 2. International Debt Securities by Country of Residence

(In billions of U.S. dollars)

\begin{tabular}{lrrrr}
\hline & \multicolumn{4}{c}{ Amounts Outstanding } \\
\cline { 2 - 4 } Countries & 2001 December & 2002 December & 2003 March & 2003 June \\
\hline & $7,507.7$ & $9,196.8$ & $9,687.7$ & $10,266.2$ \\
All countries & 579.4 & 656.9 & 676.1 & 691.9 \\
Offshore centers & 16.2 & 13.5 & 12.1 & 11.7 \\
Aruba & 2.5 & 2.3 & 3.0 & 3.2 \\
Bahamas & 24.9 & 22.4 & 27.0 & 26.3 \\
Bermuda & 380.6 & 438.9 & 449.8 & 457.3 \\
Cayman Islands & 30.9 & 39.4 & 40.4 & 42.7 \\
Hong Kong & 8.8 & 14.5 & 15.2 & 15.5 \\
Lebanon & 3.4 & 3.5 & 3.5 & 3.5 \\
Mauritius & 77.3 & 85.7 & 86.3 & 89.2 \\
Netherlands Antilles & 4.0 & 4.5 & 4.8 & 4.8 \\
Panama & 16.5 & 17.4 & 17.7 & 18.8 \\
Singapore & 9.4 & 9.3 & 10.2 & 12.4 \\
West Indies U.K. & & & & \\
\end{tabular}

Source: BIS Quarterly Review, September 2003.

37. The offshore corporations have given rise to concern from a money laundering perspective. Under current law, these companies can operate almost totally without disclosure. Although the initial founders of the company must be disclosed in the founding documents, subsequent ownership or beneficial ownership does not need to be registered publicly. In case bearer shares have been issued, no publicly available information is offered on the ultimate shareholder's identity. This information is only kept by the CSP. Although 
annual financial statements must be prepared for the benefit of the shareholders, there is neither an audit requirement nor a general publication requirement.

38. Although the articles of incorporation must include a statement on the objectives of the company, these can be very broad to the point that it is difficult to establish from the articles what the activity of the company consists of. Only financial institutions or companies of which the articles of incorporation allow the issuance of bearer shares to an aggregate amount of more than NA f. 150,000 , or which have issued bonds, are obliged to disclose their financial condition by depositing their annual statements at the Companies Registry.

39. On the other hand, these corporate entities are recently becoming less of a "black box." First, although at the company formation stage there are no requirements that the beneficial owner of the corporate entity be known, the CSPs will be obliged, under the recent State Ordinance on the Supervision of Fiduciary Companies, ${ }^{10}$ to apply KYC or customer due diligence rules. ${ }^{11}$ Second, these companies will be required to disclose much more information on their financial condition, as well as on ownership and beneficial ownership, when the Netherlands Antilles implements its commitment to the OECD. These developments will help mitigate money laundering concerns.

40. The foundation, representation, management, and domiciliation of these companies are performed by the CSPs ${ }^{12}$ active in the Netherlands Antilles. Currently, this sector consists of an estimated 200 active companies. The bulk of the CSP business is in hands of a few large companies, mostly owned by reputable banks.

41. There is concern about the relatively high number of abandoned offshore corporations, although exact figures are not available. In many of these cases, the owner has lost interest in the corporation and stops payments to the CSP, which manages the corporation, as well as annual registry fees. However, these companies can be easily sold to unknown third parties and revived, simply by paying back registry fees. The authorities have the intention to adopt new legislation that would provide the Companies Registry the authority to liquidate these corporations and clean up the registry. Under current law, there is no reliable and efficient legal framework for the removal of these defunct corporations.

${ }^{10}$ Enacted in August 2001; implementation is starting up; existing CSPs have been requested to put in their licensing applications.

${ }^{11}$ For a broader discussion of CSP supervision, see Chapter IV of this report.

${ }^{12}$ In Dutch: trust-maatschappijen. These are not to be confused with trust companies in the Anglo-Saxon legal sense. 


\section{E. Curaçao Free Trade Zone}

42. Three free trade zones are operated in the Netherlands Antilles: the Harbor Free Zone, the Airport Economic Zone, and the Industrial Park "Brievengat." All three are managed by the "Curinde" corporation, 85 percent owned by the Island Authority of Curaçao. In 2001, the Curaçao free zones processed goods to a value of US\$666 million, as shown in Table 3.

Table 3. Curaçao Free Trade Zone, Customs Value

(In millions of U.S. dollars)

\begin{tabular}{lrrrrr}
\hline & 1997 & 1998 & 1999 & 2000 & 2001 \\
\hline Total export & 227.5 & 160.6 & 338.6 & 291.5 & 310.3 \\
Total import & 173.9 & 104.8 & 302.7 & 285.8 & 355.6 \\
\hline
\end{tabular}

Source: Bank of the Netherlands Antilles.

1/ Data after 1998 understate volumes, as a result of data losses.

43. The free zones can be used either as an entrepot for the storage of goods awaiting further processing or onwards transport, or as an administrative center for movement of goods, without the goods physically moving through the free zones. A total of 152 companies are established in the three free zones in the Netherlands Antilles. These companies are permitted to export a maximum of 25 percent of their turnover to the Netherlands Antilles at normal import duties. The remaining 75 percent must be reexported to third countries. Free zone companies pay 2 percent tax on their profits.

44. The operations of the free trade zone are regulated on the basis of the State Ordinance on the Establishment of Economic Zones in the Netherlands Antilles. ${ }^{13}$ The requirements for establishment of a company within the free zones are primarily geared to the potential economic benefit for the island economy, less than to integrity or law enforcement concerns. The 85 percent state-owned economic development agency, "Curinde NV," has been given powers to decide on admission or removal of companies from the free zones. Although this application process does not involve KYC screening, all companies are required to operate a bank account in the Netherlands Antilles and, in this way, are subject to the AML rules of the Netherlands Antilles.

${ }^{13}$ National Gazette 2001, No. 18. 
45. Goods cannot be brought directly into the free zones. They arrive through the harbor or airport and are sealed upon arrival, pending customs clearance into the free zone. The outer perimeter of the free zone is monitored by the customs authorities. All goods exiting the free zone are monitored by customs at the free zone exit before entering the economic space of the Netherlands Antilles. The physical separation of the free zone has been outsourced to "Securitas," a private sector security company.

46. A vulnerability of the free zones to money laundering and unofficial trade is the large number of contractual service companies used for provision of services, ranging from security to bank services for free zone employees to cleaning services, involving 12 different companies. Although identification is required for entry into and exit from the free zones, in view of the wide variety of service providers, there is considerable scope for unauthorized entry and exit.

47. More awareness has arisen of the integrity risks associated with the use of free zones. Because of the potentially porous separation between free zones and onshore economic activities, serious concerns exist internationally with regard to the use of free zones for evading import duties, trade in illicit substances, and money laundering. No international standards exist on the maintenance of free zone integrity. However, the Caribbean Financial Action Task Force (CFATF) meeting in April 2001 adopted AML guidelines for free zone authorities, CFATF governments, and free zone enterprises.

48. Key provisions of these CFATF guidelines are:

- $\quad$ introduction of comprehensive legislative regimes for free trade zones, which should include licensing to operate in the free zones, record keeping and reporting requirements, establishment and definition of the terms of reference of the supervisory authorities over the free zones;

- $\quad$ enforcement of regulations and imposition of sanctions by supervisory authorities;

- $\quad$ AML compliance programs must be put in place, including independent reviews and internal audits; appointment of compliance officers is strongly recommended;

- $\quad$ making enterprises in the free zones subject to KYC rules and reporting suspicious transactions;

- $\quad$ requirement of the authorities to create specialized units in the free zone responsible for AML operations, training of the businesses in the free zone in AML practices, and production of AML manuals;

- $\quad$ establishment of coordination between administrative and other authorities to combat money laundering; and

- $\quad$ creation of data collection systems and taking measures to enable sharing this data with other governments. 
49. The Netherlands Antilles National Committee on combating of money laundering has installed a subcommittee that makes recommendations on the implementation of these guidelines. In this regard, Drug Enforcement Agency has made presentations to the zone free and the banking sector in June 2003 on money laundering through free zone companies.

50. The authorities should be encouraged to review the existing regulations with respect to the free zones, with a view to introducing any of these standards, insofar as they have not already been implemented in the Curaçao free zones.

\section{F. International Investment Institutions}

51. An estimated 600 offshore investment institutions offering collective investment services are administered in the Netherlands Antilles, while approximately 40 investment institutions are domiciled in the Netherlands Antilles. An estimated 15 investment institutions, mostly U.S.- and Netherlands-based, offer collective investments in the Antillean domestic market.

52. An estimated US\$10 billion is under management. ${ }^{14}$ Supervision on investment institutions was recently introduced when the National Ordinance for the Supervision of Investment Institutions and Administrators became operational on January 1, 2003. These institutions are currently in the process of applying for a license, and reliable quantitative data is not available to the authorities. The Dutch Central Bank supervises 12 offshore investment institutions established in the Netherlands Antilles, which offer investment services to Dutch residents.

53. Some of the main elements of this legislation on supervision of investment firms are the following:

- $\quad$ supervision of these investment institutions focuses on conduct of business rules, rather than on prudential concerns;

- $\quad$ separation between the manager of the investment institution and the custodian is a key element;

- a license or dispensation will be required to operate an investment institution;

- $\quad$ management and the custodian must meet fit and proper criteria;

- the custodian must be organized as a legal entity, with own funds separated from the assets of the investment institution;

${ }^{14}$ Source: Bank of the Netherlands Antilles. 
- $\quad$ investment institutions will report to the BNA on a periodic basis and shall submit audited annual financial statements to BNA;

- investment institutions shall meet requirements of the BNA with regard to integrity, expertise, financial safeguards, conduct of business, and disclosure;

- the external auditor is required to report to the supervisor any circumstance that could endanger a clean opinion with regard to the annual statements;

- the supervisor can conduct on-site inspections;

- the supervisor disposes of a range of sanctions to enforce compliance with the standards; and

- $\quad$ administrators of investment institutions will also be subject to a licensing regime.

54. The BNA will be able to issue subordinate regulations on fit and properness, conduct of business, financial strength, and disclosure. Exemption policy guidelines were developed by the bank and introduced to the sector in July 2003 .

\section{Company Service Providers}

55. In view of the potential abuse of CSPs also in other jurisdictions, for money laundering, and other illicit activities resulting from traditionally low levels of regulation and oversight of these entities, the mission has discussed these issues with the authorities in some detail.

56. With the passage of the National Ordinance of August 3, 2001 on the Supervision of Fiduciary Business (2001, No. 81) (the "CSP Ordinance"), the Netherlands Antilles have brought CSPs under the regulation of a new Supervisory Board for Fiduciary Business (Article 2 of CSP Ordinance). The mission was informed that since mid-February 2002, approximately 75 companies have registered for a CSP application and paid a license fee, and that by the May 3, 2002 deadline, another 150 companies are expected to do so.

57. The CSP Supervisory Board expects to process the license applications during the remainder of 2002, and to start actively supervising the sector in January 2003. The Board currently has a secretariat of three full-time employees; once it is clear what the demands will be for the board, additional positions may be authorized.

58. The CSP Ordinance creates a supervisory board (Article 2) to supervise the fiduciary business (Article 11(1)) consisting of five members appointed by the minister of justice for a term of five years (Article 3). The ordinance contains a broad grant of authority for the issuance of a ministerial order to promulgate rules for the board, after CSP interest groups and the board have expressed their views on the proposed decree (Article 4(4)). The funding for the board consists of licensing fees (Article 7(4)), an annual supervision fee (Article 11(2) from CSPs regulated by the board, along with "funds obtained from voluntary contributions 
from the BNA, returns from investments, and deposit accounts" (Article 5(2)). The ordinance prohibits anyone from carrying on a fiduciary business without a license and provides that licenses will only be issued to corporate entities (Article 6).

59. The ordinance sets forth requirements for license applications, including proof of identity of the shareholders, directors, and those who will act as directors of offshore companies; a declaration by each of these persons that there are no facts about such person that would cause reasonable doubt as to their integrity; and that such person has not been involved in any criminal offense (Article 7(1)). Each CSP licensed under the ordinance must submit annual financial statements to the board (Article 12(3)) and an annual compliance certificate (Article 13). The board has the power to inspect licensed CSPs and to have access to all business documents (Article 12(4)). Finally, the supervisory board has two enforcement powers that may be used on the occurrence of certain conditions: to revoke the license of the CSP (Article 16(1)) and to remove members of management (Article18(1)).

60. The mission has stated its view that the regulator should not be a newly created agency but rather the BNA; that the applications process relied too heavily on a statement by the applicant rather than an assessment by the regulator; that there were substantial gaps in addressing AML concerns such as (KYC requirements and the obligation to make unusual transaction reports; that information sharing was not fully provided for; and that enforcement measures were inadequate. ${ }^{15}$

61. The major issues that still remain to be addressed include: (1) autonomy and capacity of regulatory entity - which we have previously recommended should be the central bank; (2) scope of regulated activities; (3) the licensing process - fit and proper criteria; (4) scope of inspection powers; (5) reporting and external auditing requirements; (6) enforcement mechanisms and penalties; and (7) information sharing.

\section{Capacity and autonomy of CSP regulatory entity}

62. The agency to be designated as regulator for the company service providers must meet a number of criteria to be effective:
- authority;
- $\quad$ maximum independence from political influences;
- $\quad$ expertise in the financial area;
- $\quad$ experience in regulation and supervision; and
- $\quad$ cross sector consistency in regulation and supervision.

63. Furthermore, in view of the scarcity of resources, there is a need to use staff, office facilities, and existing agencies to the best effect. The BNA appears to meet these criteria to

${ }^{15}$ See Aide-Mémoire dated December 2000 and Attachment I. 
the greatest extent and seems a natural choice to take on the responsibilities laid down in the law.

64. The BNA already regulates banks, insurance companies, and pension funds and will in the future regulate investment institutions. In addition, this approach is consistent with an increasing trend to consolidate regulation and supervision of financial activities, as may be seen in jurisdictions such as Australia, Cayman Islands, Denmark, Gibraltar, Guernsey, the Isle of Man, Jersey, Korea, Norway, Peru, Sweden, and the United Kingdom. ${ }^{16}$ The mission was told that a legislative proposal currently being drafted in the Netherlands places the supervision of CSPs with the Netherlands Bank.

65. A related issue is that under Article 3(5) of the CSP Ordinance, a CSP supervisory board member may be dismissed "at the request of ... an interested party ... for a substantial reason." This provision should be deleted on the grounds that it is a serious diminution of the autonomy of the board and serves no countervailing purpose otherwise.

\section{BANKING SUPERVISION}

\section{A. Introduction}

66. The BNA has a strong framework within which to conduct banking supervision. The BNA is continuously reviewing its system, has strong staff and generally good practices. Laws, regulations, inspection, authority, and remedial measures provide the tools for effective supervisory oversight. However, the implementation of some of its supervisory functions would be improved by moving from a compliance orientation to a more proactive risk-based approach. This is reflected in the assessments of BCPs 8 and $16 .^{17}$

67. These concerns are the more valid, as the general business environment for local banks has deteriorated, with declining real estate values, a long period of economic decline, and the increased reluctance of the financial sector to refinance government debt. These conditions create a presumption that banks' asset quality may have declined and needs to be monitored more closely than is possible through the normal schedule of on-site inspections, which take place annually or biannually.

68. Therefore, while the supervisory system is compliant or largely compliant with the great majority of the BCPs, the BNA needs to be more proactive in its oversight of credit risk management and require banks to review their loan portfolios and report to the BNA with a higher periodicity and with more attention to actual repayment capacity. Off-site surveillance does not collect a sufficient level of detail regarding problem loan information. A significant

${ }^{16}$ Financial regulators in Cayman Islands, Gibraltar, Guernsey, the Isle of Man, and Jersey supervise CSPs.

${ }^{17}$ Also see the detailed assessment in Volume II of this report. 
component of on site examination work has been to ensure the accuracy of Charts of Accounts, which is not an effective use of supervisory resources.

69. Credit institutions are not required to review or provide specific provisions for offbalance sheet risks, which are only reviewed for specific provisions during on-site examinations. The quality of off-balance sheet exposure needs to be included more explicitly in the BNA's asset quality review. Table 4 presents an overview of the aggregate balance sheet of domestic banks of the Netherlands Antilles.

Table 4. Aggregate Balance Sheet of Commercial Banks Operating in the Domestic Banking Sector at Year-End

\begin{tabular}{|c|c|c|c|c|c|c|}
\hline & \multicolumn{2}{|c|}{2000} & \multicolumn{2}{|c|}{2001} & \multicolumn{2}{|c|}{2002} \\
\hline & $\begin{array}{l}\text { Millions } \\
\text { of NA } f \text {. }\end{array}$ & Percent & $\begin{array}{l}\text { Millions } \\
\text { of NA f. }\end{array}$ & Percent & $\begin{array}{l}\text { Millions } \\
\text { of NA f. }\end{array}$ & Percent \\
\hline \multicolumn{7}{|l|}{ Assets } \\
\hline Cash and banks & $1,268.3$ & 23.9 & $1,952.3$ & 32.7 & $1,767.1$ & 28.5 \\
\hline Investments & 264.1 & 5.0 & 261.9 & 4.4 & 582.8 & 9.4 \\
\hline Loans & $3,449.4$ & 65.1 & $3,417.8$ & 57.2 & $3,500.9$ & 56.5 \\
\hline Inv. unconsolidated subs. & 30.9 & 0.6 & 19.5 & 0.3 & 12.2 & 0.2 \\
\hline Fixed assets & 164.2 & 3.1 & 162.7 & 2.7 & 170.0 & 2.7 \\
\hline Other assets & 120.1 & 2.3 & 159.4 & 2.7 & 166.6 & 2.7 \\
\hline Total assets & $5,297.0$ & 100.0 & $5,973.6$ & 100.0 & $6,199.6$ & 100.0 \\
\hline \multicolumn{7}{|l|}{ Liabilities } \\
\hline Demand deposits & $1,421.7$ & 26.8 & $1,606.9$ & 26.9 & $1,798.0$ & 29.0 \\
\hline Savings deposits & $1,873.6$ & 35.4 & $2,176.7$ & 36.4 & $2,148.7$ & 34.7 \\
\hline Time deposits & $1,108.1$ & 20.9 & $1,276.5$ & 21.4 & $1,302.0$ & 21.0 \\
\hline Total deposits & $4,403.4$ & 83.1 & $5,060.1$ & 84.7 & $5,248.7$ & 84.7 \\
\hline Borrowings & 250.3 & 4.7 & 158.8 & 2.7 & 183.1 & 2.9 \\
\hline Other liabilities & 228.4 & 4.3 & 266.3 & 4.5 & 274.6 & 4.4 \\
\hline Total liabilities & $4,882.1$ & 92.1 & $5,485.2$ & 91.9 & $5,706.4$ & 92.0 \\
\hline Minority interest & 5.6 & 0.1 & 5.3 & 0.1 & 6.6 & 0.1 \\
\hline Subordinated debent. & 5.1 & 0.1 & 6.2 & 0.1 & 9.7 & 0.2 \\
\hline General provisions & 119.4 & 2.3 & 134.3 & 2.2 & 161.7 & 2.6 \\
\hline Capital and reserves & 284.8 & 5.4 & 342.6 & 5.7 & 315.2 & 5.1 \\
\hline Total capital & 414.9 & 7.9 & 488.4 & 8.1 & 493.2 & 0.0 \\
\hline Total liabilities and capital & $5,297.0$ & 100.0 & $5,973.6$ & 100.0 & $6,199.6$ & 100.0 \\
\hline
\end{tabular}

Source: Bank of the Netherlands Antilles. 


\section{B. Basel Core Principles Assessment_Main Findings}

\section{General}

70. With the concurrence of the BNA, the mission assessed compliance with the Basel Core Principles for Banking Supervision (Table 5), using the essential and additional criteria of the Core Principles Methodology. The assessment was based on the BNA's self assessment of compliance with the Core Principles (CP), a review of the relevant laws and regulations, interviews with the staff of the BNA and discussions with onshore and offshore banks. More detail on the motivation of the assessments is provided in the detailed assessment in Volume II of this report.

Table 5. Summary Compliance of the Basel Core Principles

\begin{tabular}{|l|c|l|}
\hline \multirow{2}{*}{\multicolumn{1}{|c|}{ Assessment Grade }} & \multicolumn{2}{|c|}{ Principles Grouped by Assessment Grade } \\
\cline { 2 - 3 } & Count & \multicolumn{1}{|c|}{ List } \\
\hline Compliant & 20 & $\begin{array}{l}1.1 ; 1.2 ; 1.3 ; 1.4 ; 1.5,1.6 ; 2 ; 3 ; 4 ; 5 ; 6,7,9,10 ; 15,20 ; 22, \\
\end{array}$ \\
\hline Largely compliant & 8 & $11 ; 24,25$ \\
\hline Materially noncompliant & 2 & $8 ; 16$ \\
\hline Noncompliant & 0 & \\
\hline Not applicable & 0 & \\
\hline
\end{tabular}

\section{Objectives, autonomy, powers, and resources (CP 1)}

71. The elements of CP 1 were found to be compliant. However, there is no explicit mention in the law of protection of the supervisory staff nor is there mention of covering the costs incurred in defending their actions while discharging their duties. However, it is understood to be implicit in the general civil law that an employer is responsible for the actions of its employees performing their duties in a responsible manner. Despite this, the BNA is going to study the possibility of including explicit legal protection for individual staff members as part of the Banking Supervision Ordinance.

\section{Licensing and structure (CPs 2-5)}

72. These criteria were found to be compliant. Licensing criteria are sufficiently broad. The BNA received 11 applications for bank licenses since 1999; 9 were granted and 2 were withdrawn. Five of the nine licenses granted were to local banks for the establishment of new international subsidiaries within the Netherlands Antilles. No applications have been denied in the past two years. The law adequately defines significant ownership and controlling interest, and there are legal requirements to obtain supervisory approval for proposed changes in ownership and control. The BNA has established adequate criteria for reviewing major acquisitions or investments by credit institutions. 


\section{Prudential regulations and requirements (CPs 6-15)}

73. Prudential regulations are generally adequate in scope. CPs 6, 7, 9, 10, and 15 were found to be compliant, and CPs 11-14 were found to be largely compliant. CP 8, loan evaluation and loan-loss provisioning, was found to be materially noncompliant. The BNA's directives on risk management are sufficiently broad, but it needs to enhance the effectiveness of both off-site surveillance and on-site examinations to ensure that its regulations are properly implemented, especially with regard to credit risk management. BNA's oversight of credit institutions' loan evaluation and loan-loss provisioning guidelines would benefit from more frequent reviews by credit institutions of their performing and nonperforming loan portfolios, improved reporting of specific provisioning for loan losses, and more frequent on-site visits. The BNA does not require credit institutions to assess and manage their interest rate risk, and it does not oversee the risk for the banking system. The mission recommended that they require the credit institutions to address this risk, and that they provide supervisory oversight of it. The BNA's oversight of internal control and internal audit was found to be largely compliant. The BNA plans to impose fines and penalties for noncompliance by credit institutions with the requirement to prepare and submit accurate Charts of Accounts. CP 15 is fully compliant as no significant deficiencies were found. ${ }^{18}$

\section{Methods of on-going supervision (CP 16-20)}

74. There are weaknesses in BNA's off-site surveillance and on-site supervision. and CP 16 was found to be materially noncompliant. CPs 17-19 were found to be largely compliant and CP 20 was found to be compliant. The oversight of credit risk management needs improvement, especially with regard to the frequency of loan portfolio review, loanloss provisioning, and the required reporting of problem loans. The BNA needs to be more proactive in monitoring trends and assessing the condition of the banking sector as a whole. In addition, it needs to develop an action plan to assess the increased risk in credit institutions' operations and the impact on earnings and capital in light of continuing weak economic conditions. In addition, the BNA should implement a program of credit risk targeted on-site examinations to allow for more frequent reviews of credit institutions' loan portfolios. The BNA should include assessments of country risk and interest rate risk in its on-going supervision. It should complete its survey on market risk and decide the extent to which market risk needs to be monitored and managed.

\section{Information requirements (CP 21)}

75. CP 21 was found to be largely compliant. The BNA requires banks to submit annual audited financial statements that are generally prepared in accordance with U.S. General Accepted Accounting Principles (GAAP), Dutch GAAP, or International Accounting

\footnotetext{
${ }^{18}$ Also see Chapter VII of this Volume and Volume II of this report.
} 
Standards. External auditors have the legal duty to report matters of material significance to the supervisor.

\section{Formal powers of supervisors (CP 22)}

76. CP 22was found to be compliant. The BNA has adequate formal powers and the authority to take corrective measures if it determines that a bank is not complying with its directives regarding solvency, liquidity, or risk management. It has the authority to restrict a bank's operations and to revoke its license. The BNA would benefit from having the ability to impose fines or penalties on senior management and/or directors and to remove management without having to threaten to revoke a credit institution's license.

\section{Cross-border banking (CP 23-25)}

77. CP 23-25 were found to be compliant The BNA has adequate cross-border banking arrangements that allow for reasonably effective supervision of offshore credit institutions. The risks posed by overseas operations of local institutions are limited. There is only one branch and one subsidiary of local banks, both in Aruba. The BNA has MoUs with Aruba, the Netherlands, and Venezuela; there is regular communication with the supervisors, both formally and informally. There are no formal arrangements with other countries and, given the number of foreign bank operations, the mission recommended the BNA to continue to arrange appropriate MoUs with foreign supervisory authorities whose credit institutions maintain operations in the Netherlands Antilles.

\section{InSURANCE ANd Pension Fund SuPERVISION}

\section{A. Insurance}

78. In 2001, net premium income for the nonlife and life, and offshore as well as onshore, amounted to 19 percent of 2001 GDP. Combined assets of these subsectors for that year amounted to 75 percent of GDP (Tables $6,7,8$, and 9). ${ }^{19}$

Table 6. Insurance Sector-Total Admissible Assets

(In millions of U.S. dollars)

\begin{tabular}{lrrrrr}
\hline & \multicolumn{2}{c}{ Life } & & \multicolumn{2}{c}{ Nonlife } \\
\cline { 2 - 3 } \cline { 5 - 6 } & 1999 & 2000 & & 1999 & 2000 \\
\hline Onshore & 645.6 & 704.1 & & 169.8 & 199.3 \\
Offshore & 21.3 & 24.0 & & $1,197.5$ & 989.3 \\
\hline
\end{tabular}

Source: Bank of the Netherlands Antilles.

${ }^{19}$ Bank of the Netherlands Antilles. 
Table 7. Insurance Companies in the Netherlands Antilles at End-2001

\begin{tabular}{lccc}
\hline & Life & Nonlife & Reinsurance \\
\hline Onshore & 11 & 16 & \\
$\quad$ Of which: & 1 & 4 & \\
$\quad$ Foreign subsidiaries & 8 & 6 & \\
$\quad$ Foreign branches 1/ & 2 & 6 & 6 \\
$\quad$ Independent 2/ & 1 & 15 & \\
Offshore & & & \\
\end{tabular}

Source: Bank of the Netherlands Antilles.

1/ Foreign branches under the nonlife column includes one in Bonaire.

2/ Independent branches under the nonlife column includes one in St.

Maarten.

Table 8. Consolidated Balance Sheet of Life Insurance Companies

(In millions of Netherlands Antilles Guilders)

\begin{tabular}{|c|c|c|c|c|c|c|}
\hline & \multicolumn{2}{|c|}{1999} & \multicolumn{2}{|c|}{2000} & \multicolumn{2}{|c|}{2001} \\
\hline & Local & Int'l & Local & Int'l & Local & Int'l \\
\hline \multicolumn{7}{|l|}{ Assets } \\
\hline \multicolumn{7}{|l|}{ Intangibles } \\
\hline Total investments & 798.4 & 31.6 & 852.3 & 30.3 & 864.8 & 34.0 \\
\hline Current assets & 211.8 & 6.4 & 253.3 & 18.8 & 264.0 & 17.8 \\
\hline Other assets & 14.7 & $\ldots$ & 10.3 & $\ldots$ & 10.5 & ... \\
\hline From separate accounts statement & 130.7 & $\ldots$ & 143.5 & $\ldots$ & 157.4 & $\ldots$ \\
\hline Total admissible assets & $1,55.6$ & 38.0 & $1,259.4$ & 49.1 & $1,296.7$ & 51.8 \\
\hline \multicolumn{7}{|l|}{ Equity, provisions, and liabilities } \\
\hline Capital & 12.5 & $\ldots$ & 12.8 & 7.1 & 10.7 & 7.1 \\
\hline Surplus & 84.9 & $\ldots$ & 89.4 & 20.7 & 99.0 & 21.9 \\
\hline Subordinated instruments & & $\ldots$ & & & & \\
\hline Technical provisions & 751.5 & $\ldots$ & 825.8 & 15.7 & 847.5 & 17.8 \\
\hline Other provisions and liabilities & 9.2 & $\ldots$ & 10.2 & 1.2 & 9.8 & 1.3 \\
\hline Current liabilities & 157.1 & $\ldots$ & 168.9 & 4.4 & 163.6 & 3.7 \\
\hline Contingent liabilities & 9.7 & $\ldots$ & 8.8 & $\ldots$ & 8.8 & $\ldots$ \\
\hline From separate accounts statements & 130.7 & $\ldots$ & 143.5 & $\ldots$ & 157.4 & $\ldots$ \\
\hline Total equity, provisions, and liabilities & $1,155.6$ & $\ldots$ & $1,259.4$ & 49.1 & $1,296.8$ & 51.8 \\
\hline
\end{tabular}

Source: Bank of the Netherlands Antilles. 
Table 9. Consolidated Balance Sheet of the Nonlife Insurance Industry

(In millions of Netherlands Antilles Guilders)

\begin{tabular}{|c|c|c|c|c|c|c|}
\hline & \multicolumn{2}{|c|}{1999} & \multicolumn{2}{|c|}{2000} & \multicolumn{2}{|c|}{2001} \\
\hline & Local & Int'l & Local & Int'l & Local & Int'l \\
\hline \multicolumn{7}{|l|}{ Assets } \\
\hline Intangibles & 0.2 & & 0.1 & & & \\
\hline Total investments & 129.5 & $2,030.8$ & 141.5 & $1,642.8$ & 139.7 & $1,914.0$ \\
\hline Current assets & 168.5 & 113.9 & 211.5 & 133.7 & 115.3 & 114.3 \\
\hline Other assets & 5.4 & 0.1 & 4.7 & 0.1 & 3.7 & \\
\hline Total admissible assets & 303.6 & 144.8 & 357.8 & $1,776.6$ & 258.7 & $2,028.3$ \\
\hline \multicolumn{7}{|l|}{ Equity, provisions, and liabilities } \\
\hline Capital & 37.1 & 113.7 & 41.9 & 115.5 & 29.2 & 146.1 \\
\hline Surplus & 35.7 & $1,012.1$ & 36.6 & 536.9 & 40.3 & 617.0 \\
\hline Subordinated instruments & 2.1 & $\ldots$ & 0.1 & $\ldots$ & 1.2 & $\ldots$ \\
\hline Technical provisions & 145.4 & 920.4 & 150.3 & $1,059.4$ & 146.2 & $1,200.5$ \\
\hline Other provisions and liabilities & 2.6 & 7.3 & 4.0 & 7.6 & 5.8 & 7.2 \\
\hline Current liabilities & 80.7 & 91.3 & 124.9 & 57.2 & 36.0 & 57.5 \\
\hline Contingent liabilities & & & & & & \\
\hline Total equity, provisions, and liabilities & 303.6 & $2,144.8$ & 357.8 & $1,776.6$ & 258.7 & $2,028.3$ \\
\hline
\end{tabular}

Source: Bank of the Netherlands Antilles.

\section{B. Insurance Supervision}

79. Insurance supervision is exercised by the BNA on the basis of State Ordinance on Insurance Supervision, enacted in 1990. Subsequently, a number of decrees were issued regulating among other areas the supervision of captive insurance companies and professional reinsurers, the submission of business plans in the context of the licensing procedure, solvency requirements for insurance companies, funeral insurance, and assessments of fees to cover the cost of supervision. ${ }^{20}$ Within the BNA, insurance and pension supervision is exercised by the Institutional Investors Supervision Department. At end-2001, these departments numbered 13 staff under the leadership of the Deputy Director. These include two actuaries, an expatriate consultant, five on-site examiners, and three offsite analysts. Additional staff is currently being recruited, including an additional actuary.

80. New developments on insurance supervision since the mission include:

- $\quad$ adjustment and update of the AML/CFT guidelines to include all insurance companies;

${ }^{20}$ National Gazette 1992, Nos. 50, 52, 53, and 55. 
- $\quad$ completion of a procedures manual for on-site inspections and off-site analysis;

- $\quad$ commencement of on-site AML inspections;

- $\quad$ preparation of a draft Procedures Manual for Market Conduct Examinations;

- $\quad$ further refinement of the on-line Annual Report Automated Statements System (ARAS) system; and

- $\quad$ finalization of a database in May 2003 to retain five years' data from the insurance companies; data are currently being entered, and staff is being trained in the use of the database.

\section{Main Findings and Recommendations}

\section{General}

81. The mission assessed observance of the Core Principles of the IAIS, based on study of the laws and regulations, interviews with BNA staff, and market participants.

\section{Organization of an insurance supervisor (Principle 1)}

82. The BNA is observant of this principle. Responsibilities of the BNA are clear and objectively stated, and the BNA is operationally and financially independent from the government, although it is capitalized by the government. It is also independent from the industry, as by law, directors and staff are prohibited from having any association with any insurer, except by taking out policies. Staff is of high quality and trained on an ongoing basis. Procedures for on-site and off-site supervisory work are in place and are clear and well documented, although some of the newer ones still await completion. It is recommended that the BNA reevaluate the resources needed to implement the planned program of on-site examinations, for the introduction of new rules and regulations, and the associated additional supervisory workload. The new regulations need to be completed as soon as possible.

83. The BNA is in the process of attracting additional staff for the insurance supervision section, including an actuary and an auditor. Per August 1, 2003, a new staff member has started work. A tight schedule of on-site examinations has been prepared, including AML/CFT. Per end-June 2003, the BNA has conducted 18 visits and on-site inspections, of which 4 full-scope inspections and the remainder targeted examinations focused on AML/CFT and investment portfolios.

84. The staff of the insurance supervision section includes two actuaries, and other staff have at least a BA in business administration or accounting. Most staff have between 10 years and 15 years experience in insurance supervision. Staff regularly attend national and international training seminars. 


\section{Licensing (Principle 2)}

85. The authorities are broadly observant of this principle.

Part 1: Companies underwriting risks in the domestic market: Legal provisions are in place, entrusting the BNA to regulate the insurance sector and designate it as the licensing authority. Appropriately rigorous licensing arrangements are in place.

Part 2: Assessment of key functionaries and business plan: The requisite legal and regulatory standards are in place. According to the Ordinance on Insurance, the BNA assess the business plan and the suitability of board members, managers, and shareholders. To assist the assessment of compliance with fit and proper criteria, a new Integrity Unit has been created, which is able to exchange information with the public prosecutor's office and the UTRC. Decisions of the BNA can be appealed before administrative and judicial bodies. A new Integrity Test has been introduced by the BNA for testing fitness and probity of managers of financial institutions.

Part 3: Reliance on insurance supervisors in other jurisdictions: reliance on the information of insurance supervisors in other jurisdictions is an integral part of the licensing process and will be strengthened when more MoUs are concluded with supervisors abroad. Licensing of captives or professional reinsurers can raise specific issues when it is incorporated abroad. In such cases, licensing should wait until satisfactory arrangements have been made for cooperation and exchange of information with the foreign supervisor. Licensing of composites should be excluded. The grounds for refusal of a license should include noncompliance with fit and proper criteria. As long as the candidate does not comply with the fit and proper requirements of the bank, no license will be issued.

86. The licensing requirements are laid down in the Special Insurance License Decree; one of the requirements is that management of the captive and professional reinsurer be fit and proper. A personal questionnaire must be completed by the person nominated as policymaker of the institution in order for the bank to evaluate this candidate.

\section{Changes in control (Principle 3)}

87. The authorities are broadly observant of this principle. There is a prior approval process included in the procedures manual that is based on Article 17 of the Insurance Ordinance. During the process of updating the Insurance Ordinance, these requirements need to be brought into the legislation. Prior approval for any changes should be required.

\section{Corporate governance (Principle 4)}

88. The authorities are broadly observant of this principle. Assessment of management and ownership takes place as described under Principle 1. For board members, the guidelines are laid down in "Guidance Notes," which also need to be given the status of a binding law or regulation. Rules on the governance of captives and professional reinsurers need to be reinforced. The guidance notes will be given the status of a regulation on the basis of 
Article 31 of the ordinance. Captives and reinsurers are not required by law to have a supervisory board. However, once they appoint a board, it should comply with the Guidance Notes. The mission's recommendation to amend the captive legislation and make it mandatory for all captives and professional reinsurers to have a supervisory board will be discussed during the coming review of the captive legislation.

\section{Internal controls (Principle 5)}

89. The authorities are broadly observant of this principle. Internal controls are a standard element in the well-established program of off-site analysis and on-site inspections. Guidance notes on internal controls - even if abided by - should be given a more binding legal status. The authorities intend to give these guidance notes the status of a regulation; the authority of the BNA to issue regulations is based on Article 31 of the ordinance.

\section{Assets (Principle 6)}

90. The authorities are broadly observant of this principle. Supervisory control of assets is outlined in supervisory procedures and the new ARAS system, but not in regulations. These procedures need to be given more binding status. The authorities intend to implement this recommendation and will issue the necessary regulations.

\section{Liabilities (Principle 7)}

91. The authorities are broadly observant of this principle. As in many other jurisdictions, financial statements and the valuation of assets and liabilities takes place according to GAAP and international standards relevant to our jurisdiction. Technical provisions are described extensively in ARAS and examined annually. The BNA is going to develop its own standards for the valuation of liabilities, whereby every effort will be made to comply with international standards.

\section{Capital adequacy and solvency (Principle 8)}

92. The authorities are broadly observant of this principle. The implementation of supervision in the Netherlands Antilles goes some way toward capital adequacy requirements that reflect the size, complexity, and risks of the insurer. IAIS has not developed standards in this field. The BNA should develop its own standards.

93. Capital adequacy requirements differ for life insurance and property/casualty insurance. Decree 52/1992, based on Articles 22 and 36 of the ordinance, requires a minimum capital margin of NA f. 400,000 (US\$220,000) for life insurance companies, unless the technical reserves, actuarially calculated and augmented by 4 percent of the technical reserves as required by Article 36 of the Ordinance, should be the higher amount. In that case, the company is obliged to maintain a solvency reserve of the higher amount. The capital adequacy requirements, therefore, are related to the business of the individual company and its risk profile, with an absolute floor of NA f. 400,000. For property and casualty (P\&C) companies the floor is NA f. 300,000 (US\$165,000) unless the reserves for 
unearned premiums, pending claims, and expected claims augmented with a 15 percent additional reserve as required by Article 36 of the ordinance is the higher amount. In that case, the higher of the two amounts should be retained for capital adequacy purposes. BNA inspections assess the adequacy of the reserves held by $\mathrm{P} \& \mathrm{C}$ companies against good international practice, and impose higher reserves as needed, based on the authority provided in Article 31 of the ordinance. Decree 52/1992 specifies the permissible assets that count toward the technical reserves. The IAIS has not developed standard methods or percentages for minimum solvency, so in this area the Netherlands Antilles should draw on their past experiences and also the experiences of other jurisdictions. There are currently no statutory minimum capital requirements in the Insurance Ordinance, and BNA relies on the requirements described above. However, the solvency requirements are under review to assess whether they need to be adjusted to reflect more closely the risks, size, and complexity of the different types of insurers. The Central Legal Bureau of the Netherlands Antilles has, in the meantime, issued statutory minimum capital requirements for insurance companies of NA f. 200,000 (US\$110,000), pending revision of the ordinance. A higher level of observance could be achieved once revised solvency requirements are introduced.

94. The solvency requirement for professional reinsurers seems to be on the low side. This needs review. Captives should also be subjected to more risk-based capital requirements. The law lays down solvency requirements for the different types of institutions. The authorities intend to review these to reflect more of the risks, size, and complexity of the different types of insurers. A higher level of compliance could be achieved once more developed solvency requirements are implemented.

\section{Derivatives and "off-balance sheet" items (Principle 9)}

95. The authorities are broadly observant of this principle. However, from a survey conducted by the authorities some time ago, it appeared that none of the insurers use these instruments. Currently, no regulation or guidance exists, although a regulation is in development based on the IAIS guidance paper. The guidance paper should be given binding status in due course. A higher level of observance could be achieved once this regulation is implemented. In the currently used-asset valuation guide developed by the BNA, guidelines on the valuation of derivatives have been included.

\section{Reinsurance (Principle 10)}

96. The authorities are observant of this principle. Annually, prior to the hurricane season, the BNA sends out a reinsurance questionnaire requesting information on catastrophe risk exposure and applicable reinsurance coverage. These documents are being reviewed for all insurance companies to determine whether the reinsurance coverage is adequate. These checks are also performed during desk and field examinations. More examiner training is needed on reinsurance. Currently, the BNA has only one reinsurance specialist. The rules on reinsurance should be given binding status. 


\section{Market conduct (Principle 11)}

97. The authorities are materially nonobservant of this principle. The proposed National Ordinance on the Insurance Brokerage Business has not yet been enacted, nor have the market conduct guidelines been published. The proposed ordinance only deals with insurance agents and brokers. Consideration could be given to supervising, either directly or indirectly (through principals or employees), all persons providing insurance advice from within the Netherlands Antilles. The government is in the process of setting up an independent alternative dispute resolution body that will enable complaints to be dealt with in an effective and affordable manner. The market conduct guidelines should be given more binding status. The proposed National Ordinance on the Insurance Brokerage Business takes account of the supervision of offshore insurance brokers. Where licensed insurers deal directly with policyholders and prospective policyholders of the general public, in other jurisdictions where there are no market conduct rules, they should abide by the market conduct guidelines of the Netherlands Antilles. The authorities will take steps to amend the current draft ordinance on the supervision of insurance intermediaries to include all persons providing insurance advice from within the Netherlands Antilles; these would also include employees of a particular insurance company providing insurance advice.

\section{Financial reporting (Principle 12)}

98. The authorities are broadly observant of this Core Principle. Similar comments apply to this section as to Principle 7. Action should be taken immediately to remedy the current practice of late submission of audited statements (including imposing fines for late reporting, based on the ordinance).

\section{On-site inspection (Principle 13)}

99. The authorities are observant of this Core Principle. A structured and tight on-site inspection program is being implemented since January 2003, and the BNA has developed a comprehensive procedures manual. The manual is finalized and will be updated periodically. The BNA keeps to the standards of the U.S.-based Society of Financial Examiners, and several of the staff of the bank are Certified Financial Examiners. The BNA should extend its on-site inspections to insurance brokers, paying special attention to AML, and market conduct aspects. A new set of AML/CFT guidelines for insurance companies has been introduced in June 2003. The BNA should follow through with more structured meetings with external auditors. The BNA has field examination procedures for captives and professional reinsurers and will resume its examination program for captives and professional reinsurers.

\section{Sanctions (Principle 14)}

100. The authorities are observant of this principle. Article 31 of the Insurance Ordinance provides for a range of corrective actions, including the issuance of a legally binding instruction and appointment of an administrator. Article 55 provides the authority to withdraw the license of an insurance company, for instance, when it is seriously 
noncompliant with any regulatory provision. The BNA should consider including within the legislation, different, specific types of directives that may be used, as well as keeping an allencompassing power. In addition, the bank should be able to impose a range of civil money penalties (not criminal fines) against individuals and the insurer/intermediary.

101. By virtue of Article 31 of the ordinance, the BNA can issue binding instructions to companies, either of a general nature or related to a specific company. For example, an insurance company that was conducting both the life and nonlife business in one legal entity was instructed to transfer the life business to another legal entity. Furthermore, it has occurred in the past that an insurance intermediary was operating as an insurance company, meaning that it was informing potential clients that it represented certain insurance companies, whereas this was not the case. The intermediary would collect the premium, issue a receipt to the policyholder, and retain the premium. The client mistakenly believes to be insured with an insurance company. In order to provide the public with more information, the Bank instructed all insurance companies to periodically publish the names of their intermediaries in the newspapers. In addition, the legislation contains certain requirements/provisions. If a company fails to comply with these, the bank can impose certain sanctions. The sanctions can be the issuance of an instruction, appointment of a silent trustee, revocation of the license, or depending on the nature of the violation, the case will be taken to court. In the above-mentioned example of the intermediary, this person was conducting the insurance business without a license. This is considered a serious violation and the bank reported the case with the public prosecutor as required in Article 122 of the ordinance.

\section{Cross-border business operations (Principle 15)}

102. The authorities are broadly observant of this core principle. All insurers operating in the Netherlands Antilles, including subsidiaries and branches of overseas insurers, need to be licensed although incidental cross-border business is permitted on a direct provision of services basis. The legislation enables the minister of finance to prohibit or impose rules on specific inwards cross-border business, if the actions of the insurer are not thought to be in the interests of local policyholders. In addition, the bank uses a provision in the law to require brokers to submit annual details of all insurers with whom business has been placed. The BNA has become more proactive in consulting with overseas insurance supervisors. BNA has frequent contact with the Dutch Insurance Supervisor and the Aruban Insurance Supervisor. Also the Trinidad and Tobago Insurance Supervisors are being consulted on certain matters. The legislation should be changed so that a licensed insurer needs to seek specific approval in order to operate cross-border.

103. Whenever the BNA, as the home supervisor, wants to conduct an examination of a branch office in another jurisdiction, the host supervisor is contacted and a joint-examination is arranged. This is also the case when a foreign supervisor wants to conduct an examination on a branch established in the Netherlands Antilles. Thus, the BNA must be officially informed of every intention of a foreign home supervisor to conduct an examination in the Netherlands Antilles. In the past, the bank has conducted joint examinations with the Aruban 
and Dutch supervisor. The conduct of on-site inspections in the Netherlands Antilles by foreign supervisors would preferably be explicitly permitted by legislation.

\section{Coordination and cooperation (Principle 16)}

104. The authorities are broadly observant of this principle. The BNA should expedite the remaining planned MoUs (taking account the requirements of the IAIS Core Principle 16) with other relevant jurisdictions and implement legislative changes to ensure that reciprocity is not mandatory when providing information to other authorities. In June 2003, the BNA has introduced revised AML/CFT guidelines to include all insurance companies (life, nonlife, captives, and professional reinsurance companies). AML controls should be extended to encompass also offshore intermediaries.

\section{Confidentiality (Principle 17)}

105. The authorities are observant of this principle. The insurance legislation requires confidentiality, and there is a gateway under which the bank can share information with other insurance supervisors. As already recommended in CP 2 and CP 16, this gateway needs to be much broader in nature and not subject to full reciprocity in every case.

\section{Anti-money laundering (Principle 18)}

106. The IAIS does not yet have a separate core principle on money laundering. Currently, Antillean AML legislation and regulation cover money laundering through insurance companies or brokers. Training is being provided to the sector.

\section{Captives and Professional Reinsurers}

107. Captive insurance companies and professional reinsurers are regulated in the 1992 State Decree on Licensing of Special Insurance. The definition of a captive insurer is given in Article 3 of the Special Decree. The decree covers insurers who, from the Netherlands Antilles, predominately insure or reinsure the risks of group or cooperative members that are outside the Netherlands Antilles and also those entities who, from within the Netherlands Antilles, exclusively write reinsurance business not coming within the above definition. This decree effectively creates a separate supervisory regime for captives and professional reinsurers. The term "captive" also includes those insurers writing nonrelated risks situated outside the Netherlands Antilles as long as these risks are subordinate to the main related risks.

108. Supervision over captives and reinsurers has many similarities with regular insurance supervision, but is overall lighter than over regular onshore insurers. This situation is an exception to the overall policy to regulate offshore and onshore financial institutions similarly.

109. The major differences in the legal requirements with respect to captives and reinsurers are as follows: 
- $\quad$ Captives are allowed to have only one managing director, as opposed to regular insurance companies, where it is required that the company should have at least two managing directors.

- $\quad$ Captives and professional reinsurers are not required to have a supervisory board; solvency requirements are based on net premiums income/net technical provisions as opposed to gross premium/gross provisions.

- $\quad$ Exemptions can be granted to captives and professional reinsurers to practice life and nonlife business in one and the same legal entity. However, separate administration, separate statements, and separate solvency margins must be maintained for each type of business.

- $\quad$ Licensing applications must comprise a detailed business plan and a three-year forecast.

- $\quad$ Once the license is issued, the BNA can make use of Article 31 of the ordinance to impose additional conditions.

- The licensing process allows little discretion to the supervisor, as the license cannot be refused on grounds other than those of noncompliance with the conditions laid down in the decree.

- $\quad$ A solvency fund must be maintained as a safeguard for policyholders, above and beyond assets that are needed to cover the technical provisions of the local branch. Thus, certain assets are ring fenced, and are to be kept with a local bank.

- $\quad$ The minimum solvency margin requirement differs for captives in that it is calculated on the net premium income (nonlife) or net fund (life), i.e., after deduction of reinsurance premiums paid. Where the margins are not met, there is no automatic revocation of the license. The BNA can request the insurer to inform the bank of the measures the insurer is taking to remedy the situation. The insurer is obliged to enter into a short-term reconstruction scheme or financing scheme approved by the bank. If these are unsuccessful by the date stipulated, the license is revoked, and the insurer is subsequently liquidated. Upon revocation, the insurer remains subject to the bank's supervision, including the control of disposal of assets. The details of the revocation are not published.

- $\quad$ As with other corporations, there is no requirement to publish the annual financial statements, although these must be filed with the BNA.

- It is possible for captives to underwrite risks of the general public situated in other jurisdictions, although these would have to be subordinate to the main risks of the captive. Even with pure captive risks, there is the possibility that the general public or corporate clients of the captive's parent would be relying on the insured having the 
appropriate cover, e.g., with casualty insurance business, including guarantee and surety and product and public liability.

110. If the bulk of the business is outside the Antilles, home-led supervision may not be appropriate. Companies incorporated in the Antilles that have branch offices in another jurisdiction must file consolidated figures with the BNA for analysis. Compliance of these figures with the regulations is verified. However, the branch office that is located abroad will also be subject to supervision of the host supervisor. Whenever there are issues of supervisory concern with respect to the branch office, the host supervisor will be contacted. The bank has in the past even conducted joint on-site examinations with foreign supervisors at branches of our local companies abroad. In those instances, agreements were made relative to which supervisor would take the lead during the examination.

\section{E. Pension Funds}

\section{Background}

111. There are currently 25 pension funds active in the Netherlands Antilles, of which 23 corporate funds and 2 state funds. ${ }^{21}$ Most corporate pension funds are associated with companies domiciled in the Netherlands Antilles. The corporate pension funds are supervised by the BNA on the basis of State Ordinance on Corporate Pension Funds (SOCPF). The state pension funds are also supervised by the BNA, on the basis of the National Ordinances on the Supervision of the APNA (Official Gazette 1997, Nos. 311 and 312).

112. Comprehensive 2000-02 figures for pension fund assets are not yet available. At year-end 1999, total assets of the pension funds (corporate and state pension funds) amounted to US\$2.31 billion (1998: US\$2.14 billion). At end-1999, assets of the state pension funds amounted to approximately US\$1.2 billion.

\section{Summary review}

113. This preliminary assessment of pension fund regulation and supervision is based on limited information. The mission has not had the opportunity to perform an in-depth study into pensions, could not ascertain the extent to which the existing schemes meet the need for pension schemes of the population, nor could it assess other sources of retirement income. Starting 2003, the BNA annual report will contain financial data and information on the pension industry. With regard to the corporate pension schemes, this preliminary review tentatively follows the topics suggested by the framework of the draft OECD Principles for the Regulation of Private Occupational Pensions Schemes. These standards have not yet been finalized, and a methodology for the assessment has not been developed.

${ }^{21}$ There are two state funds: the Civil Service Pension Fund (Algemeen Pensioen Fonds Nederlandse Antillen; APNA) and the Government Workman's Pension Fund (Gouvernements Werklieden Pensioen Fonds). 


\section{Regulatory framework}

114. Work is underway to review the 1985 law. The authorities intend to update the legislation in line with recent international developments and to make it more comprehensive, e.g., to formally include noncorporate schemes. Currently, pension schemes organized by professional associations, such as for lawyers and notaries, are in practice supervised similarly to the corporate schemes. Article 1 Paragraph 2 of this ordinance states that these groups are considered as corporations, and consequently, pension funds organized by these groups are subject to the provisions of the ordinance.

\section{Appropriate regulation of financial markets}

115. The pension funds in the Netherlands Antilles are obliged to invest approximately half their funds domestically, predominantly in government securities held to maturity, also in view of limited domestic alternative investment opportunities. Nongovernment securities investments are managed through foreign securities markets that are subject to laws and regulations in the foreign jurisdiction. Thus, the regulation of the financial markets is not a concern to the Antillean pensions sector.

\section{Rights of beneficiaries}

116. Beneficiaries only have recourse to the regular court system, based on the provisions of their contracts and the general rules of Netherlands Antilles civil law.

\section{Adequacy of private schemes}

117. There are no formal criteria for the assessment of the financial viability of the corporate pension schemes or the state schemes. However, the BNA requires annual reports and is currently designing a comprehensive annual reporting system for pension funds. An extensive scientific balance sheet is drawn up every five years, or more frequently if the BNA so requests. The law states in Article 13 that this balance sheet must show, through a thorough analysis by the actuary, that the assets are "sufficient" to cover the obligations of the fund. Article 14 specifies that investment policies must be "sound."

\section{Regulatory system and separation}

118. Supervision of corporate pension schemes, in principle, uses similar methods as for life insurers. On-site examinations have been an integral part of this system for some years and a well-documented manual is now in use. Pension schemes may be operated in the form of corporate entities, in many cases through "foundations."

\section{Funding and actuarial calculations}

119. Legislation provides no rules on funding. This area is examined by actuaries employed by the scheme manager. The actuarial reports are checked by the actuarial team of 
the BNA. Annually, an actuarial report is provided to the bank. A more extensive scientific balance sheet is required every five years, or more frequently if the BNA so requests.

\section{Supervisory structures and self-supervision}

120. Article 20 provides BNA authority to obtain any information from the fund or the employer that set up the fund and to verify this information through on-site inspections. These examinations also involve the actuarial team and have been a feature of the supervisory structure for several years. Independence of actuaries is encouraged by the BNA. In accordance with Article 5, Paragraph 1 of the SOCPF, the chair of the fund should be an independent person. When a fund does not operate to the satisfaction of the BNA, it can communicate its concern to the board of the fund, and eventually publish its recommendations, according to Article 21 of the SOCPF. If the warning is not heeded, the BNA can request the court to appoint an administrator.

121. A serious concern is the broad exemption powers Article 26 of the SOCPF provides to the minister of labor and social affairs. The minister can grant exemptions of many key provisions of the law, for instance, on the preparation of an annual report, on the "sufficiency" of the assets of the fund, on the "soundness" of the investments, limits on investments in the company that set up the fund, and other provisions, if the minister considers that "the interests of the pensioners and other interested parties are sufficiently safeguarded." This provision undermines much of the rigor of the law. Any exemption powers should rest with the supervisor, and should not be so numerous or broad as to potentially undermine the rigor of supervision. However, this is mitigated by the fact that the BNA must give its opinion/advice before the final decision is taken by the minister, who generally follows BNA's advice.

\section{Fair competition}

122. Fund management services and purchased pension plans are obtainable in the open market, and purchasers are not restricted in their choice nor are these companies restricted in their offerings of services to the pension funds.

\section{Funding}

123. The law obliges the employer to contribute at least annually. If contributions are made on a quarterly basis, payment should take place within 10 days after the termination of the quarter. The arrangements relating to payment of the contribution of the employer are to be laid down in writing. Nonpayment is to be notified to the BNA within 30 days.

\section{Investments}

124. Article 6 requires the Articles of Association of the pension funds to outline the investment policy of the fund. Article 14 merely states that investments should be made on a sound basis and Article 15 states that receivables from the employer and investments in stocks in the employer's company are permitted up to 5 percent of the fund's assets, 
increased by an amount equal to the free reserve of the fund. Additionally, the total of these claims and shares may not exceed one-tenth of the fund's assets.

125. Certain proportions of the assets must be invested domestically. Of the first tier of US\$5.6 million (NA f. 10 million) of the total provisions and liabilities, at least 40 percent must be invested locally, much of which is invested in Netherlands Antilles government securities. Of the second tier of US\$5.6 million, a minimum of 50 percent must be invested locally; of the remaining provisions and liabilities, a minimum of 60 percent must be invested locally. These rules are laid down in the Foreign Exchange Regulations. The BNA does take remedial action when necessary, e.g., where they consider that a corporate pension fund invests excessively in mortgages to employees, resulting in over dependence on the residential real estate market and the general payment capacity of the employees of the corporation.

126. Actions taken by the BNA can be summarized as follows:

- $\quad$ the BNA can call a meeting with the board of the foundation and request that the situation be changed within a specified timeframe;

- $\quad$ if the foundation fails to comply, the BNA can give an instruction to the board;

- $\quad$ if the foundation still does not comply, the BNA can publish its instructions; and

- $\quad$ ultimately, a trustee can be appointed by the court at the bank's request.

127. Article 9 of the SOCPF obliges pension funds to transfer the investment risk to an insurance company established and licensed in the Netherlands Antilles. According to Article 10, only funds that use internal actuarial and conduct of business guidelines acceptable to the BNA are not obliged to transfer the risk. The latter funds are obliged to present a scientific balance sheet to the BNA every five years, or more frequently, as the BNA may require.

\section{Winding-up}

128. Winding-up takes place according to the articles of incorporation of the funds, and the general rules on the liquidation of foundations or corporations as specified in the general bankruptcy law and companies and foundations laws. Thus far, no pension fund liquidations have led to damage to pensioner claims.

129. In the past years, several funds have been dissolved, subsequent to the dissolution of the corporation on whose behalf the fund had been set up, or because the funds were too small to be financially sufficiently resilient and diversified. Some of the funds have been dissolved and transformed into a purchased plan in order to eliminate excessive fund management costs. In some of these cases, the funds were paid out to the pensioners on a lump sum basis. No pensioner claims were lost in any of these exercises. Liquidation is 
conducted according to the rules set out in the fund's articles of incorporation, subject to the BNA compliance oversight.

\section{Disclosure and education}

130. Article11 specifies that the board of a fund shall present an audited report to the BNA on an annual basis, prepared by a qualified auditor, showing the financial condition of the fund, and that the rules are being complied with. Disclosure to interested parties takes place if - in case of special circumstances which the law does not specify in greater detail- the employer makes any contractual reservation with regard to reduction or termination of his contribution to the scheme. The intention to use this option should be immediately communicated to the board of the fund. Publication is not required. The legal entity "foundation" under which many funds are operated are obliged to issue financial statements under the companies' law. However, these statements will typically provide little specific detail on the performance of the investments.

\section{Governance}

131. The basic governance structure of pension funds is subject to the general rules in the companies and foundations laws on the governance of such corporate entities. The SOCPF contains additional specific rules. Although the law does not provide explicit fit and proper criteria, the Fit and Proper Guidelines issued by the BNA are also applicable to managers of supervised pension funds. According to Article 5 of the SOCPF, the board of a pension fund must consist of at least as many employees or former employees as there are representatives of the employer. These will jointly appoint an independent expert as chairperson of the fund. Board decisions are taken by simple majority. Board members may retain outside professional expertise to help prepare for or attend meetings. Article 6 of the law specifies the main topics that the articles of incorporation need to address, which include fund management, investment guidelines, and the procedure for the appointment of board members. Article 12 of the law provides the BNA with a veto over the appointment of an actuary or persons responsible for the preparation of the annual report. Article 20 gives the BNA authority to obtain any information it requests from the board members, any staff of the fund, and if necessary, also the employer. 


\section{Anti-Money LAUndering AND Combating FinanCing OF TERRORISM- SUMMARY ASSESSMENT ${ }^{22}$}

\section{A. Legal and Institutional Framework}

132. In general, the AML/CFT legal and institutional framework is comprehensive and well designed. There are some areas to be strengthened, as outlined below in the detailed assessment below. For purposes of this assessment, the term "financial intermediary" includes, inter alia, the following: banks; life insurance companies, including agents, subagents, and brokers; money transmitters (MTs); company service providers, such as trust companies or fiduciaries that are regulated under the ordinance on the Supervision of Fiduciary Business (CSPs); and gambling casinos. MTs are licensed and supervised by the BNA under the Foreign Exchange Ordinance and the MT Admission Requirements. Foreign exchange houses (bureau de change) are not permitted under the laws of the Netherlands Antilles.

\section{Client due diligence}

133. Under the legal and institutional framework, financial intermediaries are required to verify the identity of a person who conducts a transaction through their institution; keep a record of the evidence of a person's identity that was obtained and a record of all correspondence between the identified person and the financial intermediary; keep such records of every transaction that is conducted through the financial intermediary as are reasonably necessary to enable the transaction to be readily reconstructed at any time by the UTRC; and to report unusual transactions to the UTRC. Financial intermediaries are required to establish the identity of a customer before rendering any financial service based on an official identifying document, keep records of their identity, and review the identification when it appears that the data is no longer valid. Financial intermediaries are prohibited from rendering a financial service if the identity of the customer has not been established. If the client is a legal entity, financial intermediaries are required to verify its legal existence and structure, including the legal form, trade name, address, domicile, location of head office, and identity of all authorized agents and representatives.

\footnotetext{
${ }^{22}$ The following summary is of the AML/CFT template that appears in Volume II of this report. The headings used in the summary correspond to the headings used in Parts 1 and 2 of the AML/CFT template, which is set forth in Volume II of the report. A more detailed discussion of the issues herein may be found in the template under each of these headings. Finally, Part 1, Legal and Institutional Framework, covers the legal requirements for supervision and regulation, under the headings Client Due Diligence and Fit and Proper Test and Financial Transparency, as well as Criminalization of Money Laundering and Terrorism Finance, Confiscation of Proceeds of Crime or Assets Used to Finance Terrorism, Financial Intelligence Units, International Cooperation, and Controls and Monitoring of Cash Transactions. Part 2 covers the banking and insurance sectors. Part 3, which normally covers unregulated sectors such as MTs, was not completed since such sectors are regulated in the Netherlands Antilles.
} 
134. Financial intermediaries are required to identify complex or unusual transactions, and complex and unusual patterns of transactions that have no apparent or visible economic or lawful purpose, to examine as far as possible the background and purpose of such transactions, and report promptly the information to the UTRC. In addition, financial intermediaries are required to report all transactions over NA f. 250,000 (US\$140,000) and other transactions over NA f. 20,000 (US\$11,000) that also meet other criteria (exchange into large denominations, large foreign exchange, securities, or travelers' cheque transactions). Financial intermediaries and their officials are protected from criminal or civil suits for reporting suspicious transactions in good faith to the UTRC and are bound to secrecy in respect to information submitted to the UTRC.

\section{Fit and proper test and financial transparency}

135. In general, legislation does not explicitly refer to lack of criminal record as a fit and proper criterion for shareholders, directors, senior officers, and employees of financial intermediaries. However, under the revised March 2003 BNA Policy Rule Integrity Testing, which includes assessment of fit and proper criteria, also any criminal records are considered by the BNA in its review. Transfers of control without BNA approval are prohibited. With respect to life insurance companies, BNA approval of senior officials and shareholders is required, as is approval of changes in managing and supervisory directors. Members of the managing and supervisory board of directors, as well as shareholders of MTs are also subject to integrity and/or fit and proper tests. Banks, life insurance companies, and CSPs are all subject to licensing procedures. MTs are currently licensed under the Foreign Exchange Ordinance but will be covered under a pending legislative proposal to be licensed as a MT.

\section{Criminalization of money laundering and terrorism finance}

136. Money laundering has been made a criminal offense. Criminalization of financing of terrorism is currently not covered explicitly, but is punishable as an accessory offense to or as participation in crimes set forth in the conventions referred to in the 1999 Suppression of the Financing of Terrorism Convention.

137. Netherlands Antilles through the Kingdom of the Netherlands is a party to and has ratified the Vienna Convention. The Suppression of Terrorism Convention has been signed by the Kingdom of the Netherlands but not ratified. The Palermo Convention against Transnational Crime was signed but not yet ratified.

138. The offense of money laundering extends to a person who commits both the predicate offense and laundering as well as only laundering. It is not necessary that a person be convicted of a predicate offense to establish that assets were the proceeds of a predicate offense and to convict any person of laundering such proceeds. Predicate offenses for money laundering include all crimes. The offense of money laundering extends to all assets that represent the proceeds of crime. The offense of money laundering requires the element of knowing, including knowledge that can be inferred from objective factual circumstances. Corporate entities can also be held accountable for money laundering. 


\section{Confiscation of proceeds of crime or assets used to finance terrorism}

139. The Criminal Code provides for the seizure and forfeiture of the proceeds of crime, under protection of third party rights. Confiscation is made upon application by the public prosecutor to the court for an order to take away an illegally obtained financial advantage or object. The Palermo Convention was signed December 12, 2000 by the Kingdom of the Netherlands and also on behalf of the Netherlands Antilles but has not yet been ratified The Strasbourg Convention has been signed and ratified in 1999. Confiscation of assets of organizations found to be primarily criminal in nature (i.e., whose principal function is to perform or assist in the performance of illegal activities) is allowed. There is no provision for confiscating property of equivalent value.

\section{Financial intelligence units}

140. The UTRC has been established as an independent governmental authority. The UTRC is responsible for analyzing financial transaction reports to determine the presence of possible money laundering. Reporting parties are required to report any unusual transaction to the UTRC.

141. The UTRC may require reporting parties to provide additional documentation if necessary. The UTRC may request assistance from the BNA with respect to regulated entities, but there is no explicit provision of law that would allow information sharing between the UTRC and the BNA with respect thereto. With respect to other regulated entities or nonregulated entities, there is also no explicit authority to request assistance.

142. The UTRC has the legal authority "to collect, register, process, and analyze the data obtained by it, in order to determine whether these data may be important to prevent and detect money laundering..." (Reporting Ordinance, Article 3(a)). The UTRC has access to sources of financial and other relevant information on a real-time or expedited basis, including databases, to assist in its analysis. The UTRC is required by law to disseminate information and intelligence, either on its own initiative or upon request, to domestic authorities for investigation or action when there are reasonable grounds to suspect money laundering or terrorism financing.

\section{International cooperation in AML/CFT matters}

143. The UTRC has the authority to exchange information with foreign FIUs either on its own initiative or upon request, subject to a MoU without the need for a treaty. In addition, provisions for the sharing of information and intelligence relating to money laundering and terrorism, both formally and informally with other jurisdictions, are included in several multilateral and bilateral treaties. Mutual legal assistance is possible pursuant to a treaty and may be initiated in the Netherlands Antilles based on a determination that money laundering or a predicate crime occurred in the Netherlands Antilles, committed by a person under criminal investigation in the foreign state. There are procedures to provide effective legal assistance in criminal matters in the identification, freezing, seizure, or confiscation of proceeds of crime. Assistance may be provided if an individual is charged with money laundering or financing of terrorism only, as well as if the individual is charged with both the predicate and the money laundering offense or terrorism. Assistance may be provided even 
where there are different standards concerning the intentional elements of the crime to the extent possible under domestic law. Mutual assistance in criminal matters is effectuated primarily through bilateral treaties between the Kingdom of the Netherlands, of which the Antilles is part, and a foreign state, such as the United States, the United Kingdom, and Australia. There are also a number of treaties for mutual assistance, including, inter alia, the Strasbourg Convention.

\section{B. Banking}

\section{Organizational and administrative arrangements}

144. The Netherlands Antilles is largely compliant as regards AML organizational and administrative arrangements. The BNA undertakes on-site inspections in banks every two years, where AML policies and procedures are adequate. The money-laundering element of the on-site review includes verification of documented policy statements on ethics and professional behavior and the communication of such policies to the staff Any shortcoming or violation of the AML legislation is included in the examination report, and directives are set out to correct deficiencies in AML compliance.

145. The BNA has established a FIU as a special and separate department to assist other supervision departments with additional expertise in the area or reputational risk prevention and when conducting on-site examinations.

146. The BNA has the authority to instruct a bank to take the necessary measures with regard to compliance with the Guidelines on the Detection and Deterrence of Money Laundering ${ }^{23}$ or signs that endanger liquidity for noncompliance with the Identification and/or Reporting Ordinances.

\section{Customer identification and due diligence}

147. Compliance with the Identification Ordinance and the AML guidelines is verified by the BNA during its on-site inspections. This includes:

- $\quad$ verification of prior due diligence on resident and nonresident individuals and legal entities before rendering any financial service (Articles 2, 3, and 8 of the Identification Ordinance);

- $\quad$ verification of the adequacy of procedures to determine the identity of the ultimate beneficial owner of an account or a transaction, including individuals or legal entities, trustees, foundations, and of corporate vehicles of all kinds (Article 5 (1), (2), (3), and (4) of Identification Ordinance); Section II.1.1 (A) of the AML guidelines); and

\footnotetext{
${ }^{23}$ New AML and CFT guidelines were issued on June 16, 2003 for the banking sector: Provisions and Guidelines on Money Laundering and Terrorist Financing.
} 
- $\quad$ verification of the presence of appropriate records of identification documents and regular updating of the same their identity (Articles 3(3), 6 and 7 of the Identification Ordinance; Section II.1.1 of the AML guidelines).

148. During on-site inspections, the examiners confirm whether, when performing wire transfers, the bank requires that the originator fill out a "Source of Funds Declaration" when accepting funds from noncustomers and noncorrespondent banks. The examiners check that the bank keeps a record of the information used to identify the originator, the amount involved in the transaction, and the corresponding account number (Articles 6 (a), (b), and (c) (7) of the Identification Ordinance).

\section{Monitoring and reporting of suspicious activities}

149. This principle was assessed as compliant. During the on-site examination, the BNA verifies that the management of the banks has adopted formal statements of policy, including internal control procedures for reporting unusual transactions, adequate record keeping of transactions, and appointment of compliance officers responsible for ensuring day-to-day observance of the policy as required by the regulation.

150. The verification procedure consists of the examination of policies, procedures, and significant samples of client files, as well as verifying the existence of an adequate filing system by the compliance officer of unusual transactions detected at the bank.

\section{Record keeping, compliance, and audit}

151. The assessment of this principle resulted in a rating as compliant. In the course of its supervisory functions, the BNA confirms the designation of a senior officer or officers to be responsible for money laundering deterrence and detection. The examiners verify that client transaction records are maintained and held available for inspection for at least five years, either from the termination of the agreement or the execution of the transaction.

152. The on-site examination includes a review of the internal control systems for customer due diligence and the reporting of unusual transactions, pursuant to the relevant laws and regulations.

153. Deficiencies detected by the internal audit department or by a competent third party shall be reported to management or to the compliance officer, indicating a suggested corrective action with a deadline for compliance.

\section{Cooperation with supervisors and competent authorities}

154. The Netherlands Antilles comply with this principle. The BNA is authorized to share any information obtained in the execution of its duties as supervisor of the banking system with foreign supervisory authorities engaged in the supervision of financial markets. 


\section{Licensing and authorization}

155. This principle was found to be compliant. The law establishes the required information that allows the BNA to determine the fit and properness of major shareholders, the transparency of ownership structure, directors and senior management, and the source of the initial capital. Upon receiving an application for a license, the BNA may request all necessary additional information.

156. During the licensing process, the expertise and integrity of the proposed directors and senior management are evaluated by the BNA by means of fit and integrity criteria. The guidelines for the assessment of the fitness and probity of management and directors are outlined in the 2003 BNA Policy Rule on Integrity Testing.

157. The BNA has the authority to carry out inquiries to determine if a person or entity is doing unauthorized banking business. If the results of the inquiries confirm the performance of unauthorized banking business, the BNA will order such person or entity to stop its banking activities.

\section{Insurance}

\section{Organizational and administrative arrangements}

158. This principle was assessed as largely compliant. The BNA's "Guideline on the Detection and Deterrence of Money Laundering in Life Insurance Companies" 24 outlines an internal control system seeking to detect and deter money laundering by emphasizing on the identification of customers and prospective customers, the appointment of compliance officers, appropriate training for personnel, and the reporting of unusual transactions.

159. To ensure compliance with the recommendations made in the guidelines and test the adequacy of the mechanisms for the detection and reporting of unusual transactions, the BNA prepared a procedures manual for its staff in January 2001.

160. The Corporate Governance Guidance Notes for the Supervisory Board of Supervised Financial Institutions applies also to all insurance companies, life and nonlife. During the onsite examination, the examiners verify that the supervisory board of the life insurance company has signed an annual "Statement of Compliance" with the Corporate Governance Guidelines, certified by the company's external auditors.

\section{Customer identification and due diligence}

161. This principle was assessed as largely compliant. Life insurance companies are bound by the Identification Ordinance and, then, only as regards contracts meeting the conditions

\footnotetext{
${ }^{24}$ New AML and CFT guidelines were issued on June 16, 2003 for the insurance sector: Provisions and Guidelines on Money Laundering and Terrorist Financing.
} 
established in the law. The Identification Ordinance does not currently bind nonlife insurers, life or nonlife reinsurers, insurance brokers, agents, and captive insurers.

162. However, the new AML/CFT provisions and guidelines issued in June 2003 also apply to nonlife insurers. They provide guidance to insurers for the development of effective customer due diligence policies and procedures to discourage illegitimate transactions.

163. In January 2001, the BNA issued a procedures manual to provide guidance to examiners in ensuring that appropriate procedures to prevent, detect, and report unusual transactions are in place as required by the guidelines.

\section{Monitoring and reporting of suspicious activities}

164. This principle was assessed as noncompliant. The procedures manual for insurance examiners provides adequate guidance for the verification of the adequacy of the systems in place for the detection and internal reporting of unusual or questionable transaction, but only as regards life insurers. Base on decrees of October 2002, CFT related transactions also must be reported.

\section{Record keeping, compliance, and audit}

165. This principle was assessed as largely compliant. The procedures manual for the verification of compliance of the AML guidelines is suitable to determine whether the insurer's AML policy manual contains measures for the record keeping of questionable policyholders and transactions, audit-trail for questionable funds, and to inquire into the source of funds for the transaction.

\section{Cooperation with supervisors and competent authorities}

166. This principle was assessed as compliant. The BNA is authorized to exchange information with foreign insurance supervisors.

\section{Licensing and authorizations}

167. This principle was assessed as compliant. The BNA shall only grant a license to persons meeting the legal requirements for obtaining an insurance license (Article 11.1 of the Insurance Ordinance).

168. Grounds for revocation of an insurance license include ceasing to meet the requirements set for obtaining the license (Article 55.b of the Insurance Ordinance) and serious deficiencies in complying with laws and regulations (Article 55.e of the Insurance Ordinance) (Table 10). 
Table 10. Compliance with the FATF 40 Recommendations and Eight Special Recommendations

\begin{tabular}{|c|c|c|c|c|c|c|}
\hline \multirow{2}{*}{ FATF Recommendations $(40+8)$} & \multicolumn{5}{|c|}{ Grading } & \multirow{2}{*}{ Remarks } \\
\hline & C & $\mathbf{L C}$ & MNC & NC & $\mathbf{N} / \mathbf{A}$ & \\
\hline \multicolumn{7}{|l|}{ The FATF 40 Recommendations } \\
\hline $\begin{array}{l}\text { 1. Ratification and implementation of the Vienna } \\
\text { Convention. }\end{array}$ & $\boldsymbol{V}$ & & & & & \\
\hline $\begin{array}{l}\text { 2. Secrecy laws consistent with the } 40 \\
\text { Recommendations. }\end{array}$ & $\checkmark$ & & & & & \\
\hline $\begin{array}{l}\text { 3. Multilateral cooperation and mutual legal } \\
\text { assistance in AML. }\end{array}$ & $\checkmark$ & & & & & \\
\hline $\begin{array}{l}\text { 4. Money laundering a criminal offence (Vienna } \\
\text { Convention). }\end{array}$ & $\checkmark$ & & & & & \\
\hline $\begin{array}{l}\text { 5. Knowledge of money laundering a criminal } \\
\text { offence (Vienna Convention). }\end{array}$ & $\boldsymbol{V}$ & & & & & \\
\hline $\begin{array}{l}\text { 6. Criminal liability of corporations - and their } \\
\text { employees. }\end{array}$ & $\boldsymbol{V}$ & & & & & \\
\hline $\begin{array}{l}\text { 7. Legal and administrative conditions for } \\
\text { confiscation (Vienna Convention). }\end{array}$ & $\checkmark$ & & & & & \\
\hline $\begin{array}{l}\text { 8. Recommendations } 10-29 \text { apply to nonbank } \\
\text { financial institutions. }\end{array}$ & & $\checkmark$ & & & & \\
\hline $\begin{array}{l}\text { 9. Recommendations } 10-21 \text { and } 23 \text { apply to } \\
\text { financial services. }\end{array}$ & & 4 & & & & \\
\hline 10. Prohibition of anonymous accounts. & $\sqrt{V}$ & & & & & \\
\hline $\begin{array}{l}\text { 11. Obligation of reasonable measures for } \\
\text { customer identification. }\end{array}$ & & $\boldsymbol{V}$ & & & & \\
\hline $\begin{array}{l}\text { 12. Comprehensive record keeping ( } 5 \text { years) for } \\
\text { transactions. }\end{array}$ & $\boldsymbol{V}$ & & & & & \\
\hline $\begin{array}{l}\text { 13. Attention paid to AML risk from new } \\
\text { technologies. }\end{array}$ & & $\checkmark$ & & & & $\begin{array}{l}\text { More attention } \\
\text { needed on the } \\
\text { part of } \\
\text { authorities. }\end{array}$ \\
\hline $\begin{array}{l}\text { 14. Detection and analysis of unusual or large } \\
\text { transactions. }\end{array}$ & $\boldsymbol{V}$ & & & & & \\
\hline $\begin{array}{l}\text { 15. Reporting requirement for suspicious } \\
\text { transactions. }\end{array}$ & $\checkmark$ & & & & & \\
\hline $\begin{array}{l}\text { 16. Legal protection for good faith reporting to } \\
\text { competent authority. }\end{array}$ & & $\boldsymbol{V}$ & & & & $\begin{array}{l}\text { Provision in } \\
\text { Reporting } \\
\text { Ordinance needs } \\
\text { to be redrafted. }\end{array}$ \\
\hline $\begin{array}{l}\text { 17. No tipping off customers of reports to } \\
\text { competent authority. }\end{array}$ & $\boldsymbol{V}$ & & & & & \\
\hline $\begin{array}{l}\text { 18. Compliance with instructions for suspicious } \\
\text { transactions reporting. }\end{array}$ & $\boldsymbol{V}$ & & & & & \\
\hline $\begin{array}{l}\text { 19. Internal policies, procedures, controls, audit, } \\
\text { and training programs. }\end{array}$ & & $\boldsymbol{V}$ & & & & \\
\hline $\begin{array}{l}\text { 20. AML rules and procedures apply to branches } \\
\text { and subs abroad. }\end{array}$ & $\boldsymbol{V}$ & & & & & \\
\hline 21. Special attention given to problem countries. & $\checkmark$ & & & & & \\
\hline
\end{tabular}




\begin{tabular}{|c|c|c|c|c|c|c|}
\hline \multirow{2}{*}{ FATF Recommendations $(40+8)$} & \multicolumn{5}{|c|}{ Grading } & \multirow{2}{*}{ Remarks } \\
\hline & $\mathbf{C}$ & LC & MNC & NC & N/A & \\
\hline $\begin{array}{l}\text { 22. Detection and monitoring of cross-border } \\
\text { transportation of cash. }\end{array}$ & $\boldsymbol{V}$ & & & & & $\begin{array}{l}\text { Reporting form } \\
\text { has been } \\
\text { implemented. }\end{array}$ \\
\hline $\begin{array}{l}\text { 23. Centralization of data on currency } \\
\text { transactions. }\end{array}$ & & $\checkmark$ & & & & $\begin{array}{l}\text { Minimum amount } \\
\text { required for } \\
\text { report is } \\
\text { inadequate. }\end{array}$ \\
\hline 24. Support to the replacement of cash transfers. & $\boldsymbol{V}$ & & & & & \\
\hline $\begin{array}{l}\text { 25. Prevention of unlawful use of shell } \\
\text { corporations. }\end{array}$ & & & $\checkmark$ & & & $\begin{array}{l}\text { No actions have } \\
\text { taken place to } \\
\text { address this issue. }\end{array}$ \\
\hline $\begin{array}{l}\text { 26. Adequate AML programs in supervised } \\
\text { banks/financial institutions. }\end{array}$ & & $\boldsymbol{V}$ & & & & $\begin{array}{l}\text { More frequency } \\
\text { required for on- } \\
\text { site inspections. }\end{array}$ \\
\hline $\begin{array}{l}\text { 27. Administrative regulation of other professions } \\
\text { dealing with cash. }\end{array}$ & & & $\sqrt{2}$ & & & $\begin{array}{l}\text { No actions have } \\
\text { taken place to } \\
\text { address this issue. }\end{array}$ \\
\hline $\begin{array}{l}\text { 28. Guidelines for suspicious transactions } \\
\text { detection. }\end{array}$ & $\boldsymbol{V}$ & & & & & \\
\hline $\begin{array}{l}\text { 29. Preventing control of financial institutions by } \\
\text { criminals. }\end{array}$ & & $\boldsymbol{V}$ & & & & $\begin{array}{l}\text { Amendment of } \\
\text { Insurance } \\
\text { Ordinance } \\
\text { needed. }\end{array}$ \\
\hline 30. Recording of international flows of cash. & $\checkmark$ & & & & & \\
\hline $\begin{array}{l}\text { 31. Information gathering and dissemination about } \\
\text { AML. }\end{array}$ & $\boldsymbol{V}$ & & & & & \\
\hline $\begin{array}{l}\text { 32. International exchange of information relating } \\
\text { to suspicious transactions and to persons or } \\
\text { corporations involved. }\end{array}$ & $\boldsymbol{V}$ & & & & & \\
\hline $\begin{array}{l}\text { 33. Bilateral or multilateral agreement on } \\
\text { information exchange when legal standards are } \\
\text { different. }\end{array}$ & $\boldsymbol{V}$ & & & & & \\
\hline $\begin{array}{l}\text { 34. Bilateral and multilateral agreements and } \\
\text { arrangements for mutual assistance. }\end{array}$ & $\boldsymbol{V}$ & & & & & \\
\hline $\begin{array}{l}\text { 35. Ratification and implementation of other } \\
\text { international conventions on money laundering. }\end{array}$ & & $\boldsymbol{V}$ & & & & $\begin{array}{l}\text { Palermo } \\
\text { Convention has to } \\
\text { be ratified. }\end{array}$ \\
\hline $\begin{array}{l}\text { 36. Cooperative investigations among countries' } \\
\text { authorities. }\end{array}$ & $\boldsymbol{V}$ & & & & & \\
\hline $\begin{array}{l}\text { 37. Definition of procedures for mutual assistance } \\
\text { in criminal matters. }\end{array}$ & $\boldsymbol{V}$ & & & & & \\
\hline $\begin{array}{l}\text { 38. Authority to take expeditious actions in } \\
\text { response to foreign countries' requests. }\end{array}$ & $\boldsymbol{V}$ & & & & & \\
\hline \multicolumn{7}{|l|}{ 39. Mechanisms to avoid conflicts of jurisdiction. } \\
\hline 40. Money laundering an extraditable offence. & $\checkmark$ & & & & & \\
\hline \multicolumn{7}{|c|}{ FATF Eight Special Recommendations to Combat Terrorist Financing } \\
\hline $\begin{array}{l}\text { SR1. Take steps to ratify and implement relevant } \\
\text { United Nations instruments. }\end{array}$ & $\boldsymbol{V}$ & & & & & \\
\hline
\end{tabular}




\begin{tabular}{|c|c|c|c|c|c|c|}
\hline \multirow{2}{*}{ FATF Recommendations $(40+8)$} & \multicolumn{5}{|c|}{ Grading } & \multirow{2}{*}{ Remarks } \\
\hline & C & LC & MNC & NC & N/A & \\
\hline $\begin{array}{l}\text { SR2. Criminalize the financing of terrorism and } \\
\text { terrorist organizations. }\end{array}$ & & $\checkmark$ & & & & $\begin{array}{l}\text { Although } \\
\text { adequately } \\
\text { covered by } \\
\text { existing } \\
\text { provisions, a } \\
\text { specific law } \\
\text { criminalizing } \\
\text { terrorist financing } \\
\text { as a separate } \\
\text { offense has to be } \\
\text { introduced. }\end{array}$ \\
\hline SR3. Freeze and confiscate terrorist assets. & $\boldsymbol{V}$ & & & & & \\
\hline $\begin{array}{l}\text { SR4. Report suspicious transactions linked to } \\
\text { terrorism. }\end{array}$ & $\boldsymbol{V}$ & & & & & \\
\hline $\begin{array}{l}\text { SR5. Provide assistance to other countries' } \\
\text { terrorist financing investigations. }\end{array}$ & $\checkmark$ & & & & & $\begin{array}{l}\text { Full cooperation } \\
\text { was given in } \\
\text { checking } \\
\text { accounts on the } \\
\text { basis of the list of } \\
\text { terrorists after } \\
9 / 11 \text {. }\end{array}$ \\
\hline $\begin{array}{l}\text { SR6. Impose AML/CFT requirements on } \\
\text { alternative remittance systems. }\end{array}$ & $\checkmark$ & & & & & \\
\hline $\begin{array}{l}\text { SR7. Strengthen customer identification measures } \\
\text { for wire transfers. }\end{array}$ & $\checkmark$ & & & & & \\
\hline $\begin{array}{l}\text { SR8. Ensure that entities, in particular nonprofit } \\
\text { organizations, cannot be misused to finance } \\
\text { terrorism. }\end{array}$ & & & $\boldsymbol{V}$ & & & $\begin{array}{l}\text { Amendments to } \\
\text { legislation } \\
\text { needed. }\end{array}$ \\
\hline
\end{tabular}

Explanations: Recommendations in italics are reviewed for purposes of the legal framework, but not assessed as to implementation. The rating columns indicate the degree of compliance: $\mathrm{C}=$ compliant, $\mathrm{LC}=$ largely compliant, $\mathrm{MNC}=$ materially noncompliant, $\mathrm{NC}=$ noncompliant, and $\mathrm{N} / \mathrm{A}=$ not applicable.

\section{Strengthening the AML/CFT Framework}

\section{Client due diligence ${ }^{25}$}

- Lawyers, notaries, accountants, consultants, real estate agents, and dealers in highend goods, such as antiques, jewelry, and auctioneers are not covered under the AML/CFT framework. Consideration should be given to adopting the approach taken by the amended EU AML Directive, which would make all such entities subject to the AML framework, including customer identification and unusual transaction

${ }^{25}$ These headings correspond to the headings used in Part 1 of the AML/CFT template set forth in Volume II of the report. A more detailed discussion of the issues herein may be found in the comments section in Volume II under each of these headings. 
reporting. Requirements imposed by self-regulatory bodies for lawyers or notaries are not sufficient.

- An explicit requirement should be added to the relevant laws or decrees that when determining whether a transaction or pattern of transactions is complex or unusual, financial intermediaries must give special attention to certain transactions and to examine the background and purpose of such transactions. These include transactions with persons in jurisdictions (or, with respect to correspondent or pay-through accounts, with financial institutions) that do not have adequate systems in place to prevent or deter money laundering or terrorism financing.

- $\quad$ Consideration should be given to revising the indicators in the ministerial decree with respect to the issuing of FATF Special Recommendation VII relating to wire transfers.

- Regarding penalties for violations of laws, consideration should be given to the amendment of relevant laws to allow the BNA and other regulatory bodies, including the CSP Board, and the local Gaming Control Board, to impose, either directly or through a court order, administrative fines (or the equivalent of civil money penalties) on institutions. Administrative fines have a number of advantages, including (i) they may be imposed directly by the BNA, without the need to refer such matter to a public prosecutor, and the attendant prosecutorial discretion that may result in a low priority being given to such referral; (ii) administrative fines are subject to a lower standard of proof than criminal penalties and, therefore, are easier to impose; (iii) in amounts that are sufficiently high, such penalties may discourage those who contemplate violating the law, or raise the costs of doing so to a sufficient level, so as to act as a significant deterrent; and (iv) broad-based administrative fines and civil penalties as an enforcement mechanism are becoming more common internationally as an integral part of financial regulatory and AML laws.

- An explicit statutory requirement that financial institutions screen applicants for employment to prevent the use of their institutions by money launders or terrorists is needed. Further, statutory fit and proper criteria for directors, senior officers, and shareholders should also include explicit reference to this issue.

\section{Fit and proper test and financial transparency}

- $\quad$ A law should be adopted to put in place a system for scrutinizing possible use of shell corporations, charitable or not-for-profit foundations, or other similar entities to ensure that they are not misused by criminals, including that they do not act as conduits for criminal proceeds or terrorist financing (including to escape any asset freezing measures) or to conceal or obscure the clandestine diversion of funds intended for legitimate purposes to terrorist organizations. 


\section{Criminalization of money laundering and terrorism finance}

- $\quad$ Legislation is required to make terrorism finance a separate offense.

\section{Financial intelligence units}

- $\quad$ The BNA should conduct on-site AML inspections more frequently than once every two years; other regulators, including the CSP Supervisory Board ${ }^{26}$ and the Gaming Control Board do so as well; and target AML inspections to those institutions in each regulated sector that appear to be underreporting. In addition, the relevant laws should be amended to (i) permit information sharing between each of the regulators and the UTRC; and (ii) provide the UTRC with the authority to obtain a court order to allow the UTRC to gain entry to premises of reporting parties or to authorize the UTRC to require the BNA and other regulators to inspect a regulated entity on request by the UTRC.

- $\quad$ Consideration should be given to empowering the UTRC to (i) impose civil penalties or administrative fines, either directly or through a court order, on reporting parties for failure to make timely reports and for other violations of AML laws; and (ii) conduct compliance audits of reporting entities.

- $\quad$ Although the UTRC's budget is approved annually by the council of ministers and the parliament, approval for each purchase of goods and services must be obtained in advance by the UTRC from the ministry of finance, along with a monthly projection of planned expenditures. This approach is cumbersome and time-consuming and should be replaced by a budgetary allocation and yearly audit by the ministry or other appropriate agency of the government.

${ }^{26}$ The supervisory board has indicated that it does not expect to begin on-site inspections of CSPs before January 2003, at the earliest. 


\section{Comments on Company Service Provider Legislation}

1. In developing the legislation for CSP supervision, the Fund had delivered extensive comments. These have led to substantial improvements in the law. However, there remain a number of significant issues. The Fund would be pleased to provide technical assistance on these issues if desired by the authorities.

\section{Scope of regulated activities}

2. The limited definition of CSPs, contained in the ordinance that only includes companies, should be expanded to include any person or entity that, by way of business, engages in the provision of regulated activities. In addition, the definition of "fiduciary services" (Article $1(\mathrm{~g})$ ) is too narrow and should contain a reference to all those activities subject to regulation, including, but not limited to, the following activities: (i) the provision of premises for use as a registered office for a company; (ii) the provision of accommodation address facilities for a company; (iii) acting as a director, alternate director, officer, or secretary of companies; (iv) arranging for others to be directors, alternate directors, officers, or secretaries of companies; (v) the provision of company administration services; (vi) the safekeeping of shares and other securities; and (vii) such additional activities the supervisory authority may provide by issuance of a regulation.

\section{Fit and proper criteria}

3. The CSP ordinance requires that the regulator rely to a large extent on a statement by the applicant as to the background of shareholders, directors, and managers (Article 7(d)). Under the ordinance, the applicant's own statement is accepted as evidence that he or she will not be likely to act in an illegal or improper manner or to use the CSP for a purpose that will violate the law. The regulatory entity should be required to verify all the information provided by the applicant prior to the granting of a license. In addition, the law should also include legal authority for the regulatory entity to request information on the identity of indirect shareholders or connections to groups of controlling shareholders, not only at the time of filing the application for a license, but also on an ongoing basis. Also, there should be broad criteria in the law for 'fit and proper' qualifications for the applicant, such as having no criminal convictions, not having been declared bankrupt or having been a director or senior official of a company that has been declared bankrupt, or possessing a university degree. These broad criteria would then be elaborated in more detail in regulations pursuant to Article 4(4) of the law. Finally, the "four-eyes" principle should be required for all CSPs, i.e., that at least two managers be working at the CSP at all times.

\section{Inspection powers}

4. The powers mentioned in Article 12(4) should also include the regulator's authority to inspect and get access to books, records, accounts, and documents of former CSPs only in respect of such transactions, matters, or circumstances as occurred or existed when it was the holder of a CSP's license. In addition, such inspection powers should also be exercised in 
relation to any person or entity that, on reasonable grounds, is suspected by the supervisory entity of carrying on or to have previously carried on, business as a CSP without a license.

\section{Reporting and external audit requirements}

5. The financial statements requirement of Article 13 of the CSP ordinance is not sufficient. The ordinance should expressly require that CSPs prepare, in accordance with generally accepted accounting principles, annual accounts audited by an independent auditor. In addition, CSPs should also be required to furnish to the supervisory entity the annual audited accounts together with (i) a written confirmation of an independent auditor that the annual accounts have been prepared as required under the existing rules and regulations; and (ii) a certificate of compliance issued by an independent auditor that the CSP is in compliance with its obligations under the specific regulations set forth for CSPs. The ordinance should also include special provisions requiring that the external auditor report to the supervisory entity any irregularities it may find in its examination.

\section{Enforcement mechanisms and penalties}

6. Based on broadly defined grounds - such as a threat to the integrity of the financial services industry, a threat to the financial soundness of the CSP, unfit ownership and/or management, and improper conduct of business - the ordinance should be revised to provide the regulator with the authority to take, for instance one or more of the following actions:

- $\quad$ issue a written directive requiring that action be taken by the CSP;

- impose conditions to the license with regard to specified activities;

- $\quad$ require the appointment of a special auditor at the expense of the CSP;

- $\quad$ require the appointment of an advisor;

- $\quad$ require the appointment of a temporary administrator or conservator to manage the affairs of the CSP under the direction of the supervisory entity;

- $\quad$ impose a range of civil money penalties in amounts sufficiently high to discourage failure to comply with the law;

- $\quad$ remove, suspend, and bar controlling shareholders, directors, managers, auditors, and employees not only from the affairs of a specified CSP, but also from future involvement in any CSP; and

- $\quad$ revoke the license of a CSP and liquidate it. 


\section{Information sharing}

7. The ordinance should establish the rules for information sharing between the regulator and other agencies within the Netherlands Antilles (such as the BNA) as well as with regulators, financial intelligence units, and prosecutors in foreign jurisdictions. For these purposes, the supervisory entity should be authorized to furnish data and information received through its performance of duties. The supervisory entity should ascertain that it has been adequately guaranteed that the data or information will not be used for a purpose other than that for which it was furnished, that the secrecy of the furnished data or information has been adequately guaranteed, and that the information is provided on the basis of reciprocity. 